\title{
Hints on T cell responses in a fish-parasite model: Enteromyxum leei induces differential expression of T cell signature molecules depending on the organ and the infection status
}

M. Carla Piazzon ${ }^{1}$, Itziar Estensoro ${ }^{1 \dagger}$, Josep A. Calduch-Giner ${ }^{2+}$, Raquel del Pozo ${ }^{1}$, Amparo Picard-Sánchez ${ }^{1}$ Jaume Pérez-Sánchez ${ }^{2}$ and Ariadna Sitjà-Bobadilla ${ }^{*}$ (I)

\begin{abstract}
Backgroud: Enteromyxum leei is a myxozoan parasite that produces a slow-progressing intestinal disease. This parasite invades the paracellular space of the intestinal epithelium and progresses from the posterior to the anterior intestine. The aim of the present study was to gain insights into fish $T$ cell responses in the gilthead sea bream-E. leei infection model using a PCR-array with 30 signature molecules for different leukocyte responses in head kidney, spleen, anterior and posterior intestine.

Results: The PCR-array results suggest that E. leei induced migration of T cells from head kidney to intestines where $T_{H 1}, C T L$ and $T_{H 17}$ profiles were activated and kept in balance by the upregulation of regulatory cytokines. These results were partially validated by the use of cross-reacting antibodies and BrdU immunostaining to monitor proliferation. Zap70 immunostaining supported the increased number of T cells in the anterior intestine detected by gene expression, but double staining with BrdU did not show active proliferation of this cell type at a local level, supporting the migration from lymphohaematopoietic tissues to the site of infection. Global analyses of the expression profiles revealed a clear separation between infected and exposed, but non-infected fish, more evident in the target organ. Exposed, non-infected animals showed an intermediate phenotype closer to the control fish.

Conclusions: These results evidence a clear modulation of the T cell response of gilthead sea bream upon E. leei infection. The effects occurred both at local and systemic levels, but the response was stronger and more specific at the site of infection, the intestine. Altogether, this research poses a promising basis to understand the response against this important parasite and establish effective preventive or palliative measures.
\end{abstract}

Keywords: Myxozoa, Teleost, Gilthead sea bream, T lymphocytes, Cytokines

\footnotetext{
*Correspondence: ariadna.sitja@csic.es

${ }^{+}$Itziar Estensoro and Josep A. Calduch-Giner contributed equally to this

work.

${ }^{1}$ Fish Pathology Group, Institute of Aquaculture Torre de la Sal (IATS-CSIC),

Ribera de Cabanes, Castellón, Spain

Full list of author information is available at the end of the article
}

(c) The Author(s). 2018 Open Access This article is distributed under the terms of the Creative Commons Attribution 4.0 International License (http://creativecommons.org/licenses/by/4.0/), which permits unrestricted use, distribution, and reproduction in any medium, provided you give appropriate credit to the original author(s) and the source, provide a link to the Creative Commons license, and indicate if changes were made. The Creative Commons Public Domain Dedication waiver (http://creativecommons.org/publicdomain/zero/1.0/) applies to the data made available in this article, unless otherwise stated. 


\section{Background}

Gilthead sea bream (Sparus aurata), a marine teleost species, is the main farmed fish in the Mediterranean [1]. One of the pathogens that threatens gilthead sea bream culture is the myxozoan intestinal parasite Enteromyxum leei. Myxozoans are obligate endoparasitic metazoans belonging to the phylum Cnidaria. Currently, more than 2000 myxozoan species have been described. They typically present a two-host life-cycle involving invertebrates and vertebrates as definitive and intermediate hosts, respectively [2]. The invertebrate host of E. leei is still unknown, but fish-to-fish transmission is feasible [3]. Enteromyxum leei slowly and progressively invades the intestinal epithelium of the host inducing loss of appetite and poor food conversion rates, leading to macroscopic disease signs such as emaciation, diminished growth and condition factor, cachexia and eventually death [4]. The parasite colonizes first the posterior intestinal segment and progresses to the anterior portion invading the middle intestine lastly [4]. Currently, there are no preventive or curative measures against this disease. Thus, several studies have been conducted to understand the immune responses elicited by the parasite in order to manage infections. E. leei induces a massive hyperplasia of the intestinal lamina propria-submucosa due to recruitment and proliferation of heterogeneous leukocytes [5]. More specifically, E. leei is known to induce B cell responses at a local level, with increased numbers of intestinal $\operatorname{IgM}^{+} \mathrm{B}$ cells and increased transcription of secreted and membrane $\operatorname{IgM}$ and $\operatorname{Ig} T$ [6, 7]. Recruitment of mast cells and depletion of acidophilic granulocytes have also been described in infected gilthead sea bream intestine [8]. Interleukin gene expression profiles elicited by $E$. leei infections were characterized by an early pro-inflammatory profile that later switched to an anti-inflammatory pattern in infected posterior intestinal segments [9]. Indisputably, this parasite regulates the immune response, mainly at a local level (intestine), but also systemically. The progression pattern of the disease, where the parasite is only present at the anterior intestine at later infection stages, indicates that different responses are taking place at the different intestinal segments. So far, the $\mathrm{T}$ cell response in this infection model has not been characterized. Thus, this study constitutes the first step for understanding the $\mathrm{T}$ cell response of gilthead sea bream upon infection with $E$. leei.

$\mathrm{T}$ lymphocytes are critical components of the adaptive immune system in vertebrates. They recognize specific antigens through the $\mathrm{T}$ cell receptor (TCR). The TCR is associated with the CD3 complex, responsible for the intracellular signal transduction, which includes recruitment and activation of ZAP70 and LCK kinases [10]. T cells are subdivided in two major subtypes depending on their function. $\mathrm{CD}^{+}$cytotoxic $\mathrm{T}$ lymphocytes (CTLs) directly kill cells by the crosslinking of death receptors such as Fas [11] or by releasing cytolytic effector molecules such as perforin or granzymes [12]. CD4 ${ }^{+}$helper T cells $\left(\mathrm{T}_{\mathrm{H}}\right)$ coordinate specific immune responses by releasing different types of cytokines depending on the nature of the invading microorganism or threat. In mammals, upon activation, $\mathrm{CD} 4^{+} \mathrm{T}$ cells proliferate and differentiate into effector $\mathrm{T}_{\mathrm{H}}$ cells. $\mathrm{T}_{\mathrm{H}}$ cells can be further subdivided in different subsets, including $\mathrm{T}_{\mathrm{H} 1}, \mathrm{~T}_{\mathrm{H} 2}$, $\mathrm{T}_{\mathrm{H} 17}$ and $\mathrm{T}_{\text {reg }}$, according to their distinct cytokine secretion patterns and their immunomodulatory effect [13]. These subsets represent different states of activation with certain degrees of plasticity rather than an endpoint terminal differentiation $[14,15] . \mathrm{T}_{\mathrm{H} 1}$ fate is driven by the transcription factor Tbet and is aimed to control intracellular infections by producing effector cytokines such as IFN $\gamma$ and TNF $\alpha$ and inducing CTLs. $\mathrm{T}_{\mathrm{H} 2}$ cells are characterized by the expression of the transcription factor GATA3 and the release of cytokines like IL4 and IL13, mediating B cell activation and antibody production to face extracellular infections [16]. $\mathrm{T}_{\mathrm{H} 17}$ cells express the transcription factor ROR $\gamma$ and secrete IL17A, IL17F, IL21 and IL22 to control extracellular bacteria and fungi [17]. FOXP3 is the transcription factor expressed in $T_{\text {reg }}$ cells. $T_{\text {reg }}$ cells are implicated in the regulation of the immune response and maintaining self-tolerance by producing regulatory cytokines such as IL10 and TGF $\beta$ [18]. It is important to mention that the different subsets are not exclusive. The presence or regulation of a certain cytokine does not indicate the absolute occurrence of a particular $\mathrm{T}$ cell subtype. $T$ cell responses are complex and the expression of multiple cytokines, surface molecules and transcription factors are needed to draw a full picture of the type of response that can be occurring.

Homologs of most of the surface markers, cytokines and transcription factors associated with $\mathrm{T}$ cell responses have been identified in many teleost species $[19,20]$. To date, we cannot assert that fish and mammalian $\mathrm{T}$ cell responses are equivalent, but the functional studies conducted so far indicate a strong degree of conservation of these phenotypes [21].

The aim of the present study was to gain insight into fish $\mathrm{T}$ cell responses by using the gilthead sea bream-E. leei infection model and the expression pattern of an extensive newly designed panel of signature genes for different $\mathrm{T}$ cell responses. Markers for B cells and other leukocytes were also studied. The parallel use of cross-reacting commercial antibodies allowed for the validation of the expression results for some markers (Zap70 and Tbet) at protein levels. The overall picture obtained from this study improves our currently limited knowledge on fish $\mathrm{T}$ cells and defines how this response can be regulated in the intestine upon a parasitic infection.

\section{Methods}

Fish, experimental infection and sampling procedure Gilthead sea bream juvenile specimens (mean weight \pm SEM $13.7 \pm 0.27 \mathrm{~g}$ ) from a commercial fish farm were 
checked by PCR (18S ribosomal RNA gene) and histological analyses $[4,22]$ to be specific pathogen free and clinically healthy, and were transported to the IATS-CSIC facilities (Castellón, Spain). Fish were kept in $5 \mu \mathrm{m}$-filtered sea water, with natural photoperiod and temperature (ranging from 22 to $26.5^{\circ} \mathrm{C}$ ) and fed ad libitum with a commercial diet throughout all the experiment. After a 6-week acclimatization period, 100 fish with an average weight of $24.4 \mathrm{~g}$ (SEM $=0.99 \mathrm{~g})$, were allocated in four $90 \mathrm{l}$ tanks (25 fish/tank). All tanks had the same conditions of temperature, water quality and oxygen concentration. Day-length and water temperature followed the natural changes at IATS latitude $\left(40^{\circ} 5^{\prime} \mathrm{N}, 0^{\circ} 10^{\prime} \mathrm{E}\right.$, ranging from 22 to $26.5^{\circ} \mathrm{C}$ over the course of the experiment) and the salinity of seawater was $37.5 \mathrm{~g} / \mathrm{l}$. The oxygen content of outlet water always remained higher than $75 \%$ saturation. Fish were starved for $48 \mathrm{~h}$ and animals from two replicated tanks were intubated anally with $0.2 \mathrm{ml}$ of $E$. leei-infected intestinal scrapings [recipient (RCPT) groups] as described in [3]. Fish in the other two replicated tanks were intubated with the same volume of PBS to constitute the control (CTRL) groups. Ten weeks post-intubation (p.i.), 5 fish/tank (10 fish/group) were sacrificed with an overdose of the anaesthetic MS-222 (0.1 g/l; Sigma-Aldrich, St. Louis, MO, USA)) and pieces of head kidney, spleen, anterior and posterior intestines were collected in RNAlater (Qiagen, Hilden, Germany) and stored at $4{ }^{\circ} \mathrm{C}$ until RNA isolation. In parallel, samples of head kidney, spleen, anterior, middle and posterior intestine were fixed in $10 \%$ buffered formalin for histological procedures. Samples from each fish were individually identified to compare results obtained from the different assays.

\section{RNA extraction and reverse transcription}

RNA from head kidney, spleen, anterior and posterior intestines was extracted using MagMAX ${ }^{\mathrm{m}}$ - -96 total RNA isolation kit (Applied Biosystems, Foster City, CA, USA ). The RNA concentration and quality was determined using a Nanodrop 2000c (Thermo Scientific, Wilmington, DE, USA) and the integrity was assessed on an Agilent 2100 Bioanalyzer (Santa Clara, CA, USA). RNA integrity number (RIN) values were always between 8 and 10. To avoid genomic DNA contamination, 500 ng of RNA from each sample were treated with DNaseI amplification grade (Invitrogen, Carlsbad, CA, USA ) prior to reverse transcription. Reverse transcription of $500 \mathrm{ng}$ of input RNA was performed using the High-Capacity cDNA Archive Kit (Applied Biosystems). All procedures were performed following each manufacturer's instructions.

\section{Gene expression analyses}

Real-time (RT) quantitative PCR was carried out using the CFX96 Connect $^{\text {tw }}$ Real-Time PCR Detection System
(Bio-Rad, Hercules, CA, USA) in a 96-well layout designed for simultaneously profiling the genes of interest for each tissue and individual. The primers used in this study (Additional file 1: Table S1) were selected to detect target genes characteristic of the specific responses to be studied. The primers were designed and/or checked for specificity by datamining of the gilthead sea bream transcriptomic database [23] (http://nutrigroup-iats.org/seab reamdb/). Out of the 30 sequences used in this study, 16 were described for the first time in gilthead sea bream and uploaded to GenBank (Additional file 1: Table S1). All primers were checked to have similar efficiencies and higher than $90 \%$ (ranging from 90.17 to 102.69), and the correct product size was assessed in a $1 \%$ agarose gel. Each RT reaction of $20 \mu \mathrm{l}$ contained $3.3 \mathrm{ng}$ of total input cDNA sample, $5 \times$ PyroTaq EvaGreen qPCR Mix Plus (Cultek Molecular Bioline, Madrid, Spain) and specific primers at a final concentration of $0.45 \mu \mathrm{M}$. The PCR reaction conditions consisted of an initial denaturation step at $95{ }^{\circ} \mathrm{C}$ for $3 \mathrm{~min}$, followed by 40 cycles of denaturation for $15 \mathrm{~s}$ at $95^{\circ} \mathrm{C}$ and annealing/extension for $60 \mathrm{~s}$ at $60^{\circ} \mathrm{C}$. The specificity of the reactions was verified by visual analysis of melting curves for each reaction performed. Fluorescence data acquired during the PCR extension phase were normalized by the delta-delta Ct method [24]. Four potential housekeeping genes ( $\beta$-actin, elongation factor $1 \alpha, \alpha$-tubulin and $18 S$ rRNA) were previously tested for stability using the GeNorm software. The most stable reference gene among conditions in each tissue was $\beta$-actin and it was used in the normalization procedure.

\section{Histological infection diagnosis}

Parasite diagnosis was performed on anterior, middle and posterior intestinal segments fixed in $10 \%$ buffered formalin, embedded in paraffin, $4 \mu \mathrm{m}$-sectioned and stained with Giemsa following standard procedures. Infection intensity was semiquantitatively evaluated in each intestinal segment using a scale from 1 (lowest) to 6 (highest) as previously described [3]. Non-infected segments were scored as 0 .

\section{Immunohistochemical analyses}

To validate the PCR-array results, the sequences of the gilthead sea bream $\mathrm{T}$ cell specific molecules were checked for homology with their mammalian counterparts in order to identify commercial cross-reacting antibodies to be used in immunohistochemical studies. This search produced two candidate antibodies, one against Zap70 [Zap-70 (99F2) Rabbit mAb; Cell Signaling Technologies, Leiden, The Netherlands] that had already been validated for other fish species [25], and other against Tbet (TBX21 PA5-28881 Rabbit pAb; Thermo Fisher, Rockford, IL, USA). The epitopes were more than $75 \%$ similar with long stretches of identical amino acids between gilthead sea 
bream and the target species. Possible cross-reactivity with undesired proteins was ruled out by BLAST analysis using the gilthead sea bream transcriptomic database [23] (http://nutrigroup-iats.org/seabreamdb/). In all immunohistochemical studies, a negative control without the primary antibody was included.

In order to characterize actively proliferating cells, bromodeoxyuridine (BrdU) DNA labelling was performed as previously described [26]. Briefly, $24 \mathrm{~h}$ prior to sampling, fish were intracoelomically injected with 100 mg 5-bromo-2'-deoxyuridine (BrdU; Sigma-Aldrich, St. Louis, MO, USA per kg of fish weight).

Samples of anterior and posterior intestine from three animals that showed high (RCPT4, RCPT5 and RCPT7) and low (CTRL4, CTRL5 and CTRL10) expression levels of zap70 and tbet (see Additional file 2: Table S2) were selected for immune staining. Four-micrometer-thick paraffin sections were collected on Super-Frost-plus microscope slides (Menzel-Gläser, Braunschweig, Germany), dried overnight, deparaffinised and hydrated. All incubations were performed in a humid chamber, at room temperature. The washing steps consisted of $5 \mathrm{~min}$ immersion in TTBS (20 $\mathrm{mM}$ Tris- $\mathrm{HCl}, 0.5 \mathrm{M} \mathrm{NaCl}, 0.05 \%$ Tween $20, \mathrm{pH} 7.4$ ) and 5 min immersion in TBS (without Tween 20), unless otherwise stated. An antigen retrieval step was performed by boiling the samples in citrate buffer $\mathrm{pH} 6$ for $20 \mathrm{~min}$ followed by one washing step in TBS. The endogenous peroxidase activity was blocked by incubation in hydrogen peroxide $0.3 \% \mathrm{v} / \mathrm{v}$ in distilled water $\left(\mathrm{H}_{2} \mathrm{O}: \mathrm{H}_{2} \mathrm{O}_{2}\right.$ in a 9:1 proportion) for $30 \mathrm{~min}$. Slides were washed and blocked 30 min with TBS 1.5\% normal goat serum (Vector Laboratories, Burlingame, CA, USA). After washing, they were incubated with the rabbit anti-Zap70 or rabbit anti-Tbet antibodies 1:50 and 1:100, respectively, in TBS 1\% BSA for $2 \mathrm{~h}$. Then, samples were washed again and incubated with a biotinilated goat anti-rabbit antibody (Vector Labs) 1:200 in TBS $1.5 \%$ normal goat serum for $1 \mathrm{~h}$. The slides were subsequently washed, incubated for $1 \mathrm{~h}$ with the avidin-biotin-peroxidase complex $(\mathrm{ABC}$, Vector Labs), washed and developed by incubating with 3,3'-diaminobenzidine tetrahydrochloride chromogen (DAB, Sigma-Aldrich, St. Louis, MO, USA) for 2-4 min. The reaction was stopped with deionized water and the slides were counterstained for 5 min with Gill's haematoxylin before being dehydrated and mounted for light microscopy examination.

To assess whether the higher number of Zap $70^{+}$cells observed in infected anterior intestine were due to active proliferation of resident cells, a double staining with anti-BrdU and anti-Zap70 antibodies was performed as previously described [26] with some modifications. After antigen retrieval, slides were incubated in $\mathrm{HCl} 2 \mathrm{~N}$ for 30 min, blocked in PBS, 5\% BSA, 0.5\% Triton X-100 and subsequently incubated for two hours with mouse Mab
anti-BrdU clone BU-33 (1:500, Sigma) and rabbit anti-Zap70 (1:50) in PBS at room temperature (RT). After two washes for $5 \mathrm{~min}$ with PBS $0.1 \%$ Tween 20, the samples were incubated for $1 \mathrm{~h}$ with $10 \mu \mathrm{g} / \mathrm{ml}$ of goat anti-mouse alexa fluor 488 (Invitrogen) and goat anti-rabbit Texas red (Vector Labs), washed again, stained with DAPI and mounted in aqueous mounting medium for fluorescence microscopy examination. For this study, the anterior intestines of three fish with high expression of zap70 and high number of $\mathrm{Zap} 70^{+}$cells (RCPT4, RCPT5 and RCPT7) were used. Three samples per fish were examined in order to determine the number of double positive cells.

\section{Data processing and statistical analyses}

Differences in gene expression were calculated comparing RCPT fish $(n=10)$ with CTRL fish $(n=10)$ values using GraphPad PRISM v.5.03 and R statistical software v.3.0.2 [27]. For statistical analyses, gene expression data were log-transformed (LN). For normally distributed data, differences were evaluated using Student's t-test and one-way ANOVA followed by the Tukey post-hoc test for multiple comparisons. When conditions were not met, non-parametric tests (Mann-Whitney-Wilcoxon or Kruskal-Wallis followed by Dunn's test) were used. The significance level was set at $P<0.05$ unless otherwise stated. Principal components analyses (PCA) were performed using individual gene expression values and the default prcomp $\mathrm{R}$ function. Hierarchical cluster analyses were performed using the default hclust $\mathrm{R}$ function. Visualizations were constructed using the factoextra (v.1.0.4) and gplots (v.3.0.1) R packages. Heatmaps were made using mean values for each gene, tissue and group using the heatmap. 2 function from the gplots $\mathrm{R}$ package centring and scaling the values per row.

\section{Results \\ Infection status}

Ten weeks after E. leei anal intubation, the prevalence of infection in the 10 sampled fish/group was $70 \%$ in the RCPT group and $0 \%$ in the CTRL group. The RCPT group showed significantly lower weight, size and condition factor than the CTRL group, evidencing the typical infection signs induced by this parasite [4] (Table 1). The seven RCPT fish that were E. leei-positive by histological observations $\left(\mathrm{RCPT}^{+}\right)$showed even more pronounced disease signs, particularly weight and size (Table 1) and high intensity of infection in the posterior intestine. Two of these fish were also positive in the anterior intestine, and only one scored positive in the middle intestine (Table 2). RCPT fish negative for the parasite $\left(\mathrm{RCPT}^{-}\right)$showed less pronounced disease signs with size (ANOVA: $F_{(2,17)}=22.67, P<0.0001$ ) and weight (ANOVA: $F_{(2,17)}=21.65, \quad P<0.0001$ ) 
Table 1 Recipient (RCPT) fish showed characteristic disease signs of Enteromyxum leei infection. Mean prevalence of infection, weight, size and condition factor $\left(100 \times\right.$ weight/size $\left.{ }^{3}\right)$ of the fish used in this study

\begin{tabular}{lllll}
\hline Group & Prevalence of infection (\%) & Mean weight \pm SEM $(\mathrm{g})$ & Mean size \pm SEM (cm) & Mean condition factor \pm SEM \\
\hline CTRL & 0 & $85.41 \pm 6.54^{\mathrm{a}}$ & $14.55 \pm 0.37^{\mathrm{a}}$ & $2.71 \pm 0.04^{\mathrm{a}}$ \\
RCPT & 70 & $64.95 \pm 6.89^{*}$ & $13.37 \pm 0.43^{*}$ & $2.61 \pm 0.06^{*}$ \\
RCPT $^{+}$ & 100 & $59.43 \pm 7.70^{\mathrm{b}}$ & $13.04 \pm 0.52^{\mathrm{b}}$ & $2.58 \pm 0.07^{\mathrm{b}}$ \\
RCPT $^{-}$ & 0 & $77.83 \pm 13.41^{\mathrm{a}}$ & $14.17 \pm 0.60^{\mathrm{a}}$ & $2.67 \pm 0.15^{\mathrm{a}, \mathrm{b}}$ \\
\hline
\end{tabular}

Gilthead sea bream were exposed (RCPT, $n=10$ ) or not (CTRL, $n=10)$ to the parasite $E$. leei by anal intubation and sampled after 10 weeks. Asterisks $(*)$ indicate significant differences with the CTRL group (t-test, $P<0.05)$. The analysis was also performed separating RCPT fish positive (RCPT $\left.{ }^{+}, n=7\right)$ and negative (RCPT,$n=3$ ) for the parasite by histological diagnosis (Table 2). Different superscript letters indicate statistical differences among groups for each of the parameters (ANOVA, $P<0.05$ )

significantly higher than the $\mathrm{RCPT}^{+}$group and not significantly different from the CTRL group, and an intermediate condition factor between $\mathrm{RCPT}^{+}$and CTRL fish (Table 1).

\section{Leukocyte markers are differentially expressed upon Enteromyxum leei infection}

The expression of $21 \mathrm{~T}$ cell master transcription factors, receptors, enzymes and signature cytokines was used to identify the $\mathrm{T}$ cell responses in gilthead sea bream head kidney, spleen, anterior and posterior intestines upon infection with E. leei. Middle intestine was not included in the study because only one fish scored positive in this segment, thus no statistical analyses could be performed with the subsequent results. To complete the study, six B cell specific molecules and specific markers for nonspecific cytotoxic cells (NCCs), eosinophilic granulocytes and macrophages were included in the array (Additional file 1: Table S1). The individual expression relative to the $\beta$-actin for each of these 30 genes is shown in Additional file 2: Table S2.

Enteromyxum leei infection induced downregulation of $\mathrm{T}$ cell markers in head kidney. Both pan T cell markers

Table 2 Evaluation of infection intensity per intestinal segment in recipient (RCPT) fish. Enteromyxum leei infection was semiquantitatively evaluated using a scale from 0 (no parasite observed in the segment) to 6 (maximum infection intensity). All CTRL fish scored 0 in all segments

\begin{tabular}{llll}
\hline Fish & $\mathrm{Al}$ & $\mathrm{Ml}$ & $\mathrm{Pl}$ \\
\hline RCPT1 & 6 & 6 & 6 \\
RCPT2 & 0 & 0 & 6 \\
RCPT3 & 0 & 0 & 6 \\
RCPT4 & 0 & 0 & 0 \\
RCPT5 & 0 & 0 & 6 \\
RCPT6 & 0 & 0 & 0 \\
RCPT7 & 0 & 0 & 5 \\
RCPT8 & 0 & 0 & 6 \\
RCPT9 & 0 & 0 & 0 \\
RCPT10 & 3 & 0 & 5 \\
\hline A & 0 . & 0 &
\end{tabular}

Abbreviations: $\mathrm{Al}$, anterior intestine segment; $\mathrm{MI}$ middle intestine segment; $\mathrm{Pl}$, posterior intestine segment [zap70 (t-test: $\left.t_{(18)}=6.497, P<0.0001\right)$ and $c d 3 \zeta$ (t-test: $\left.\left.t_{(18)}=5.841, P<0.0001\right)\right]$ and the specific $\mathrm{T}_{\mathrm{H}}[c d 4-1$ $\left(\mathrm{t}\right.$-test: $\left.t_{(18)}=4.983, P<0.0001\right)$ and $c d 4-2\left(\mathrm{t}\right.$-test: $t_{(18)}=$ 2.325, $P=0.03)]$ and CTL [cd8 $\alpha$ (t-test: $t_{(18)}=3.427, P=$ $0.003)$ and $c d 8 \beta$ (t-test: $\left.\left.t_{(18)}=3.694, P=0.0017\right)\right]$ receptors were significantly downregulated in the head kidney of the RCPT group when compared to the CTRL group. No significant effect on $\mathrm{T}$ cell responses was found in spleen, but the significantly higher expression of nccrp1 (t-test: $\left.t_{(18)}=3.265, P=0.0043\right)$, epx (t-test: $t_{(18)}=3.99$, $P=0.0009)$ and mpeg1 (t-test: $t_{(17)}=1.78, P=0.09$ ) points to a higher presence of NCCs, eosinophils and macrophages in RCPT spleen. Anterior intestine of RCPT fish showed a significant increase in $\mathrm{T}$ cell markers, for both $\mathrm{T}_{\mathrm{H}}$ and CTLs cells (zap70 t-test: $\mathrm{t}_{(18)}$ $=3.398, P=0.0032$; $c d 3 \zeta$ t-test: $t_{(15)}=4.461, P=0.0005$; $c d 4-1$ t-test: $t_{(17)}=2.729, P=0.014 ; c d 4-2$ t-test: $t_{(14)}=$ 3.897, $P=0.0016 ; c d 8 \alpha$ t-test: $t_{(18)}=2.631, P=0.017$; $c d 8 \beta$ t-test: $\left.t_{(18)}=2.602, P=0.018\right)$. Type 1 signature transcription factors and cytokines (tbet t-test: $t_{(18)}=$ 4.076, $P=0.0007$, tnfo t-test: $t_{(18)}=1.837, P=0.09$ and ifny t-test: $\left.t_{(18)}=5.55, P<0.0001\right)$, ill17alf $\left(\mathrm{t}\right.$-test: $t_{(18)}=$ 2.197, $P=0.041)$ and CTL receptors and enzymes $(c d 8 \alpha$, cd8 $\beta$, gzma (t-test: $t_{(18)}=4.869, P<0.0001$ ) and $p r f 1$ (t-test: $\left.\left.t_{(18)}=1.741, P=0.049\right)\right)$ were upregulated in $\mathrm{RCPT}$ anterior intestine, together with a general upregulation of B cell molecules (t-test: $m I g M$ t-test: $t_{(18)}=$ 2.538, $P=0.021 ; \operatorname{IgD}$ t-test: $t_{(18)}=2.249, P=0.037$; pax5 t-test: $t_{(17)}=3.017, P=0.007 ; \operatorname{sg} M \mathrm{t}$-test: $t_{(18)}=2.364, P$ $=0.0295)$ and no change in innate cell markers. In the posterior intestine of RCPT fish, type 1 response signature genes (tbet t-test: $t_{(18)}=2.856, P=0.0105$; ifny t-test: $\left.t_{(18)}=4.511, P=0.0003\right)$, il6 (t-test: $t_{(18)}=2.489$, $P=0.0228), i l 4 / 13 a$ (t-test: $\left.t_{(18)}=2.26, P=0.0365\right)$, illialf (t-test: $t_{(18)}=3.813, P=0.0013$ ) and the B cell markers were upregulated $\left(m \operatorname{Ig} M\right.$ t-test: $t_{(18)}=4.315, P$ $=0.0004 ;$ pax5 t-test: $t_{(18)}=3.833, P=0.0012 ; \operatorname{sig} M$ t-test: $\left.t_{(18)}=4.389, P=0.0004\right)$. The upregulation of gzma (t-test: $\left.t_{(18)}=4.151, P=0.0006\right)$, however, was not consistent with the downregulation of the other CTL markers $\left(g z m b\right.$ t-test: $t_{(18)}=2.411, P=0.027$; prf1 t-test: $\left.t_{(18)}=2.843, P=0.011\right)$ (Table 3). Significant upregulation 
Table 3 Enteromyxum leei exposure induces the most significant changes in intestine

\begin{tabular}{|c|c|c|c|c|c|}
\hline Cell types & Gene & Head kidney & Spleen & Anterior intestine & Posterior intestine \\
\hline \multicolumn{6}{|l|}{ T cells } \\
\hline \multirow[t]{2}{*}{ Pan T cell } & zap70 & $0.63 \pm 0.04^{*}$ & $0.82 \pm 0.07$ & $1.57 \pm 0.15^{*}$ & $1.23 \pm 0.13$ \\
\hline & $c d 3 \zeta$ & $0.62 \pm 0.06^{*}$ & $1.09 \pm 0.06$ & $1.63 \pm 0.16^{*}$ & $0.97 \pm 0.09$ \\
\hline \multirow[t]{2}{*}{$T_{H}$ cells } & $c d 4-1$ & $0.50 \pm 0.04^{*}$ & $0.91 \pm 0.13$ & $1.44 \pm 0.16^{*}$ & $1.07 \pm 0.11$ \\
\hline & $c d 4-2$ & $0.70 \pm 0.11^{*}$ & $1.25 \pm 0.18$ & $1.59 \pm 0.10^{*}$ & $1.22 \pm 0.12$ \\
\hline \multirow[t]{2}{*}{ CTLs } & $c d 8 a$ & $0.53 \pm 0.06^{*}$ & $0.84 \pm 0.10$ & $1.92 \pm 0.34^{*}$ & $0.89 \pm 0.14$ \\
\hline & $c d 8 \beta$ & $0.47 \pm 0.07^{*}$ & $0.80 \pm 0.16$ & $1.69 \pm 0.26^{*}$ & $0.79 \pm 0.09$ \\
\hline \multirow[t]{3}{*}{ Transcription factors } & tbet & $1.03 \pm 0.12$ & $0.94 \pm 0.09$ & $2.17 \pm 0.27^{*}$ & $1.67 \pm 0.21 *$ \\
\hline & gata3 & $0.72 \pm 0.07$ & $0.82 \pm 0.09$ & $0.74 \pm 0.11$ & $1.22 \pm 0.13$ \\
\hline & foxp3 & $0.59 \pm 0.06^{*}$ & $1.02 \pm 0.14$ & $0.99 \pm 0.13$ & $1.23 \pm 0.20$ \\
\hline \multirow[t]{9}{*}{ Driver/effector cytokines } & tnfa & $1.04 \pm 0.21$ & $1.86 \pm 0.43^{0.08}$ & $1.34 \pm 0.13^{0.09}$ & $4.38 \pm 2.96$ \\
\hline & ifny & $0.93 \pm 0.08$ & $1.05 \pm 0.04$ & $3.57 \pm 0.45^{*}$ & $6.22 \pm 1.15^{*}$ \\
\hline & il12(p40) & $0.49 \pm 0.06$ & $1.53 \pm 0.40$ & $0.70 \pm 0.12$ & $0.62 \pm 0.16^{0.07}$ \\
\hline & $i / 4 / 13 a$ & $0.93 \pm 0.19$ & $1.89 \pm 0.43^{0.08}$ & $1.07 \pm 0.16$ & $3.22 \pm 0.97^{*}$ \\
\hline & $114 / 13 b$ & $0.91 \pm 0.07$ & $0.72 \pm 0.09^{0.06}$ & $0.91 \pm 0.08$ & $1.00 \pm 0.09$ \\
\hline & il6 & $2.09 \pm 0.83$ & $0.81 \pm 0.13$ & $1.95 \pm 0.70$ & $10.34 \pm 3.75^{*}$ \\
\hline & il10 & $0.92 \pm 0.09$ & $1.34 \pm 0.13^{*}$ & $2.04 \pm 0.28^{*}$ & $1.56 \pm 0.25^{*}$ \\
\hline & $\operatorname{tgf} \beta$ & $1.05 \pm 0.15$ & $1.27 \pm 0.18$ & $0.77 \pm 0.09$ & $0.54 \pm 0.04 *$ \\
\hline & $i l 17 a / f$ & $2.15 \pm 1.27$ & $2.08 \pm 0.60$ & $7.09 \pm 2.75^{*}$ & $7.28 \pm 1.63^{*}$ \\
\hline \multirow[t]{3}{*}{ Cytotoxic enzymes } & gzma & $0.91 \pm 0.19$ & $1.73 \pm 0.26^{0.06}$ & $9.32 \pm 1.69^{*}$ & $10.97 \pm 2.40^{*}$ \\
\hline & gzmb & $1.13 \pm 0.20$ & $1.22 \pm 0.15$ & $1.10 \pm 0.22$ & $0.50 \pm 0.07^{*}$ \\
\hline & prfi & $0.89 \pm 0.12$ & $1.02 \pm 0.07$ & $2.08 \pm 0.60^{*}$ & $0.54 \pm 0.07^{*}$ \\
\hline \multicolumn{6}{|l|}{ B cells } \\
\hline \multirow[t]{4}{*}{ B cells } & $m \lg M$ & $0.81 \pm 0.12$ & $1.05 \pm 0.16$ & $2.92 \pm 0.75^{*}$ & $3.55 \pm 0.57^{*}$ \\
\hline & $m \lg T$ & $0.68 \pm 0.09^{0.06}$ & $0.58 \pm 0.12^{*}$ & $1.65 \pm 0.37$ & $1.75 \pm 0.47$ \\
\hline & $\lg D$ & $0.97 \pm 0.12$ & $0.90 \pm 0.18$ & $1.86 \pm 0.36^{*}$ & $1.92 \pm 0.50^{0.09}$ \\
\hline & pax5 & $0.93 \pm 0.10$ & $0.92 \pm 0.13$ & $1.59 \pm 0.22^{*}$ & $2.49 \pm 0.35^{*}$ \\
\hline \multirow[t]{2}{*}{ Plasma cells } & $s \lg M$ & $1.05 \pm 0.16$ & $1.23 \pm 0.15$ & $13.54 \pm 5.30^{*}$ & $7.46 \pm 1.46^{*}$ \\
\hline & $\operatorname{slg} T$ & $0.44 \pm 0.23$ & $1.00 \pm 0.22$ & $10.35 \pm 7.8^{0.09}$ & $104.29 \pm 89^{0.09}$ \\
\hline \multicolumn{6}{|l|}{ NCC cells } \\
\hline NCC & nccrp 1 & $1.09 \pm 0.11$ & $1.93 \pm 0.28^{*}$ & $0.87 \pm 0.16$ & $0.99 \pm 0.11$ \\
\hline \multicolumn{6}{|l|}{ Myeloid cells } \\
\hline Eosinophils & $e p x$ & $1.09 \pm 0.08$ & $3.62 \pm 0.63^{*}$ & $2.44 \pm 1.02$ & $1.18 \pm 0.31$ \\
\hline Macrophages & mpeg1 & $1.15 \pm 0.18$ & $1.45 \pm 0.27^{0.09}$ & $0.83 \pm 0.11$ & $0.92 \pm 0.11$ \\
\hline
\end{tabular}

Mean \pm SEM of the fold changes of the 30 studied genes in RCPT fish $(n=10)$ calculated relative to the CTRL group $(n=10)$ in each tissue. Bold values indicate significant up- (values $>1$ ) or downregulation (values $<1$ ). Asterisks $\left(^{*}\right)$ indicate significant differences at $P<0.05$. Superscript numbers indicate the $P$-values between 0.05 and 0.1

of $i l 10$ was found in spleen (t-test: $t_{(18)}=2.345, P=0.031$ ), anterior (t-test: $\left.t_{(18)}=3.49, P=0.0026\right)$ and posterior (t-test: $\left.t_{(17)}=2.541, P=0.021\right)$ intestinal segments of RCPT animals.

To determine the $\mathrm{T}_{\mathrm{H} 1} / \mathrm{T}_{\mathrm{H} 2}$ balance, the ratios tbet / gata3 and ifny / il4/13a were calculated for each organ in CTRL and RCPT fish (Table 4). In CTRL fish, the profile of head kidney and spleen was $\mathrm{T}_{\mathrm{H} 1}$-skewed in comparison to intestine, which was $\mathrm{T}_{\mathrm{H} 2}$-skewed, as both ratios were significantly lower in intestine than in head kidney and spleen (tbet / gata3 ANOVA: $F_{(3,36)}=25.82, P<0.0001$; ifny / il4/13a ANOVA: $\left.F_{(3,36)}=7.572, P=0.0005\right)$. When comparing CTRL with RCPT fish, the ratios did not change in lymphohaematopoietic tissues. In anterior intestine, a significant increase in both ratios (tbet / gata3 t-test: $t_{(18)}=5.928, P<0.0001 ; i f n \gamma / i l 4 / 13 a$ t-test: $t_{(18)}=$ 
Table 4 Enteromyxum leei induces a shift towards a $T_{H 1}$ environment in the intestine of gilthead sea bream

\begin{tabular}{|c|c|c|c|c|c|c|c|c|}
\hline \multirow{2}{*}{$\begin{array}{l}\text { Organ } \\
\text { Group }\end{array}$} & \multicolumn{2}{|l|}{ Head kidney } & \multicolumn{2}{|l|}{ Spleen } & \multicolumn{2}{|c|}{ Anterior intestine } & \multicolumn{2}{|c|}{ Posterior intestine } \\
\hline & $\overline{C T R L}$ & RCPT & $\overline{C T R L}$ & RCPT & $\overline{C T R L}$ & RCPT & $\overline{C T R L}$ & RCPT \\
\hline tbet / gata3 ratio & $3.90 \pm 0.43^{\mathrm{a}}$ & $5.10 \pm 0.73$ & $2.54 \pm 0.40^{\mathrm{a}}$ & $2.65 \pm 0.23$ & $0.53 \pm 0.09^{b}$ & $1.45 \pm 0.13^{*}$ & $0.94 \pm 0.14^{b}$ & $1.13 \pm 0.10$ \\
\hline ifny / il4 / 13a ratio & $6.72 \pm 3.08^{\mathrm{a}}$ & $4.16 \pm 1.62$ & $18.35 \pm 5.14^{a}$ & $9.79 \pm 2.45$ & $1.06 \pm 0.33^{b}$ & $2.63 \pm 0.52^{*}$ & $0.59 \pm 0.10^{b}$ & $1.74 \pm 0.38^{*}$ \\
\hline
\end{tabular}

The $\mathrm{T}_{\mathrm{H} 1} / \mathrm{T}_{\mathrm{H} 2}$ balance was assessed as the ratio of tbet / gata3 and ifny / il4 / 13a expression values for each individual fish in the study. Data are shown as mean \pm SEM for $n=10$ fish. Asterisks (*) indicate significant differences between E. leei-exposed (RCPT) and control (CTRL) groups within each organ (t-test, $P<0.05$ ). Different superscript letters indicate significant differences in the CTRL groups among all organs within each calculated ratio (ANOVA, $P<0.05$ )

2.552, $P=0.02$ ) indicated a shift to a $\mathrm{T}_{\mathrm{H} 1}$ profile. In the posterior intestine of RCPT fish, the ifn $\gamma / i l 4 / 13 a$ ratio increased (t-test: $\left.t_{(18)}=2.883, P=0.0099\right)$, but the $t$ bet I gata3 remained unchanged.

\section{Higher numbers of Zap70 ${ }^{+}$and Tbet $^{+}$cells are present in infected intestines}

The higher expression of zap70 and tbet in infected fish intestine was also observed at protein levels by immunohistochemistry. A moderate number of Zap $70^{+}$lymphocyte-like cells were observed in CTRL anterior (Fig. 1a) and posterior (Fig. 1b) intestine. These cells were located in the base of the epithelium forming a one-cell-thick layer. Zap70 ${ }^{+}$ cells were visibly more abundant in RCPT anterior intestine (Fig. 1c), forming thicker layers at the base of the epithelium. Posterior intestine from RCPT fish showed a moderate number of $\mathrm{Zap}^{+} 0^{+}$cells with a more disorganized pattern, appearing also in the lamina propria-submucosa. The amount of Zap $70^{+}$cells in RCPT posterior intestines was not visibly different from what was observed in CTRL fish (Fig. 1d).

CTRL fish intestines showed scarce and dispersed Tbet $^{+}$ cells, appearing mainly at the base of the epithelium. Positive cells were difficult to locate and no more than one or two cells were present per field of observation (Fig. 1e, f). In RCPT fish intestine, Tbet $^{+}$cells were visibly more numerous, mainly at the base of the epithelium and between the enterocytes in anterior intestine (Fig. 1g), or also in the lamina propria-submucosa at the posterior intestine (Fig. 1h).

\section{Zap70 ${ }^{+} \mathrm{T}$ cells were not actively proliferating at the sampling time}

RCPT anterior intestines that showed high expression of zap70 and high abundance of Zap $70^{+}$cells were further studied to assess whether these higher numbers were due to active proliferation. As expected for this fish-parasite model [26], BrdU positive nuclei were abundant in RCPT anterior intestines. These proliferating cells were mainly located at the epithelium with a morphology corresponding to epithelial cells although some smaller nuclei at the base of the epithelium and even in the lamina propria-submucosa were observed. However, in all of the three fish examined, the nuclei of the $\mathrm{Zap} \mathrm{O}^{+}$cells did not show reactivity with the anti-BrdU antibodies, indicating that $\mathrm{T}$ cells were not proliferating, at least in the last $24 \mathrm{~h}$ prior to the sampling (Fig. 2).

\section{The expression of $\mathrm{T}$ cell signature molecules correlates} with infection status in the target organ

Hierarchical cluster analysis of the expression values for all genes related to $\mathrm{T}$ cell responses, considering all organs and individuals, showed that all CTRL fish clustered together, whereas RCPT fish had more variability, clustering in three different branches (Fig. 3a). Three RCPT fish appeared in the CTRL cluster, namely RCPT4, RCPT6 and RCPT9. Interestingly, these three RCPT fish scored 0 for parasite presence in all intestinal segments $\left(\mathrm{RCPT}^{-}\right.$, Table 2). Principal components analysis supported this distinction (Fig. 3b). The centroids of both groups showed a clear separation in the two principal components, which explain in total $75 \%$ of the variability. The three $\mathrm{RCPT}^{-}$ fish appeared closer to the CTRL cluster and their variability among each other was low.

Considering that $E$. leei's target organ is the intestine and taking into account that the most drastic changes in gene expression were observed in that organ (Table 3), PCA was also performed for each organ separately, to assess whether changes were tissue specific or systemic. Variability in overall expression values of $\mathrm{T}$ cell signature molecules in head kidney and spleen of CTRL and RCPT fish was low (Fig. 4a, b). Individual variability was higher than group variability thus, no clear group separation could be observed within lymphohaematopoietic organs. By contrast, in the intestine, the variability of the RCPT group was significantly higher and CTRL and RCPT fish appeared clearly separated (Fig. 4c, d). This effect was more pronounced in the posterior intestine (Fig. 4d), where the different infection status become evident. $\mathrm{RCPT}^{-}$fish clustered close together near the CTRL group evidencing that the highest and more specific response is taking place in this organ and this particular segment.

\section{Exposed but non-infected fish display an intermediate phenotype between control and infected fish}

A new analysis of the gene expression values was performed, considering three groups, namely CTRL, $\mathrm{RCPT}^{+}$(fish positive for the parasite in at least one intestinal segment) and $\mathrm{RCPT}^{-}$(exposed fish where no parasite was detected). The heatmaps in Fig. 5 show the differential expression of all genes in the three different groups and four tissues. Significant changes in head kidney and spleen were scarce and did not particularly 


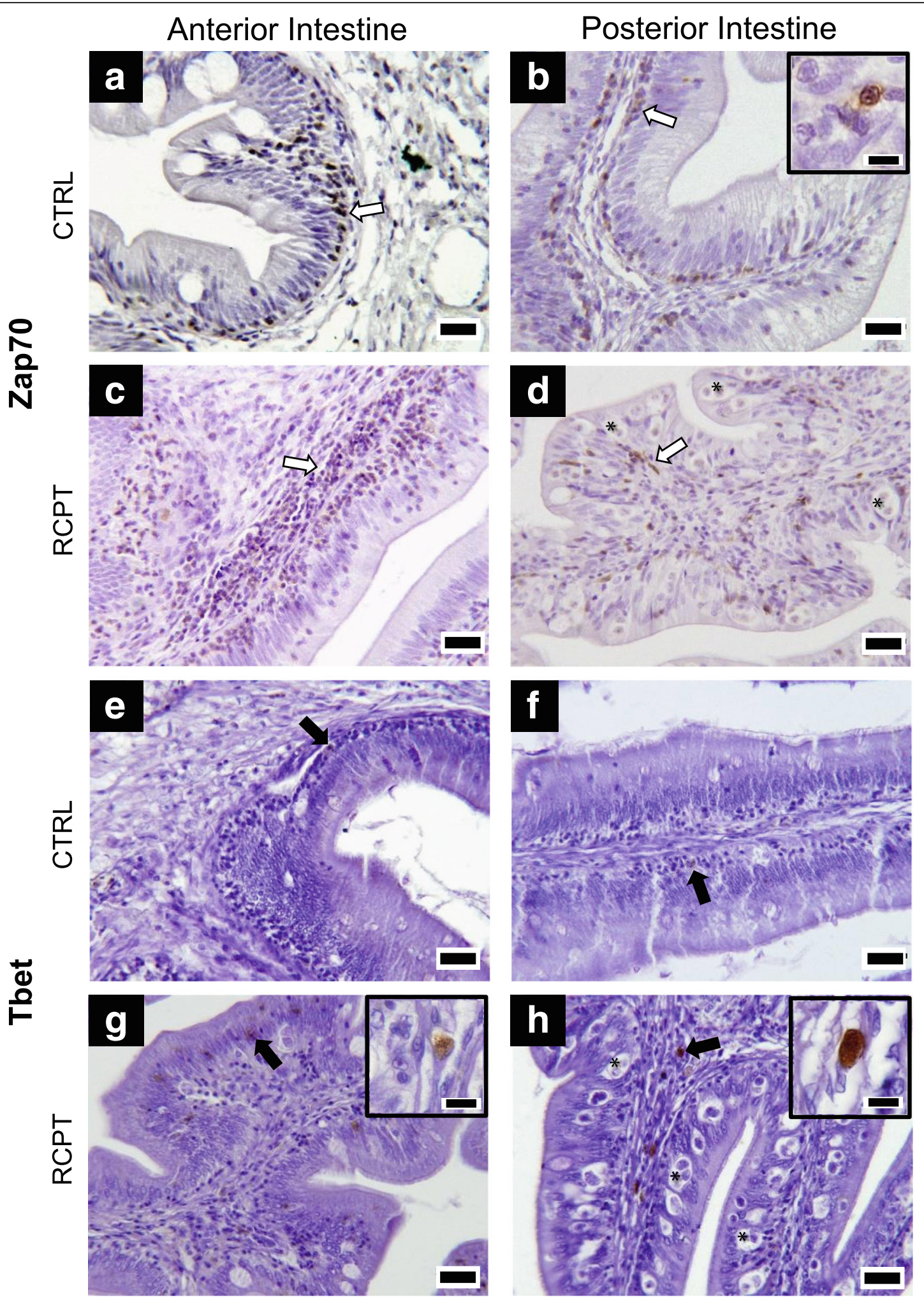

Fig. 1 Zap $70^{+}$and Tbet $^{+}$cells are more abundant in E. leei infected fish. Representative micrographs of anterior $(\mathbf{a}, \mathbf{c}, \mathbf{e}, \mathbf{g})$ and posterior $(\mathbf{b}, \mathbf{d}, \mathbf{f}, \mathbf{h})$ intestines that showed either low [control fish (CTRL): $\mathbf{a}, \mathbf{b}, \mathbf{e}, \mathbf{f}$ ] or high [recipient fish (RCPT): $\mathbf{c}, \mathbf{d}, \mathbf{g}, \mathbf{h}$ ] zap70 or tbet gene expression, stained with an antiZap70 (a, b, $\mathbf{c}, \mathbf{d})$ or an anti-Tbet $(\mathbf{e}, \mathbf{f}, \mathbf{g}, \mathbf{h})$ antibodies. White arrows point to some representative Zap70 ${ }^{+}$cells. Black arrows point to representative Tbet ${ }^{+}$ cells. Some parasites are labeled with asterisks $\left(^{*}\right)$ in the posterior intestine images (d, $\left.\mathbf{h}\right)$. Scale-bars: $20 \mu \mathrm{m}$. Insets in $\mathbf{b}, \mathbf{g}$ and $\mathbf{h}$ show immunoreactive cells at higher magnification. Inset scale-bars: 5 um 


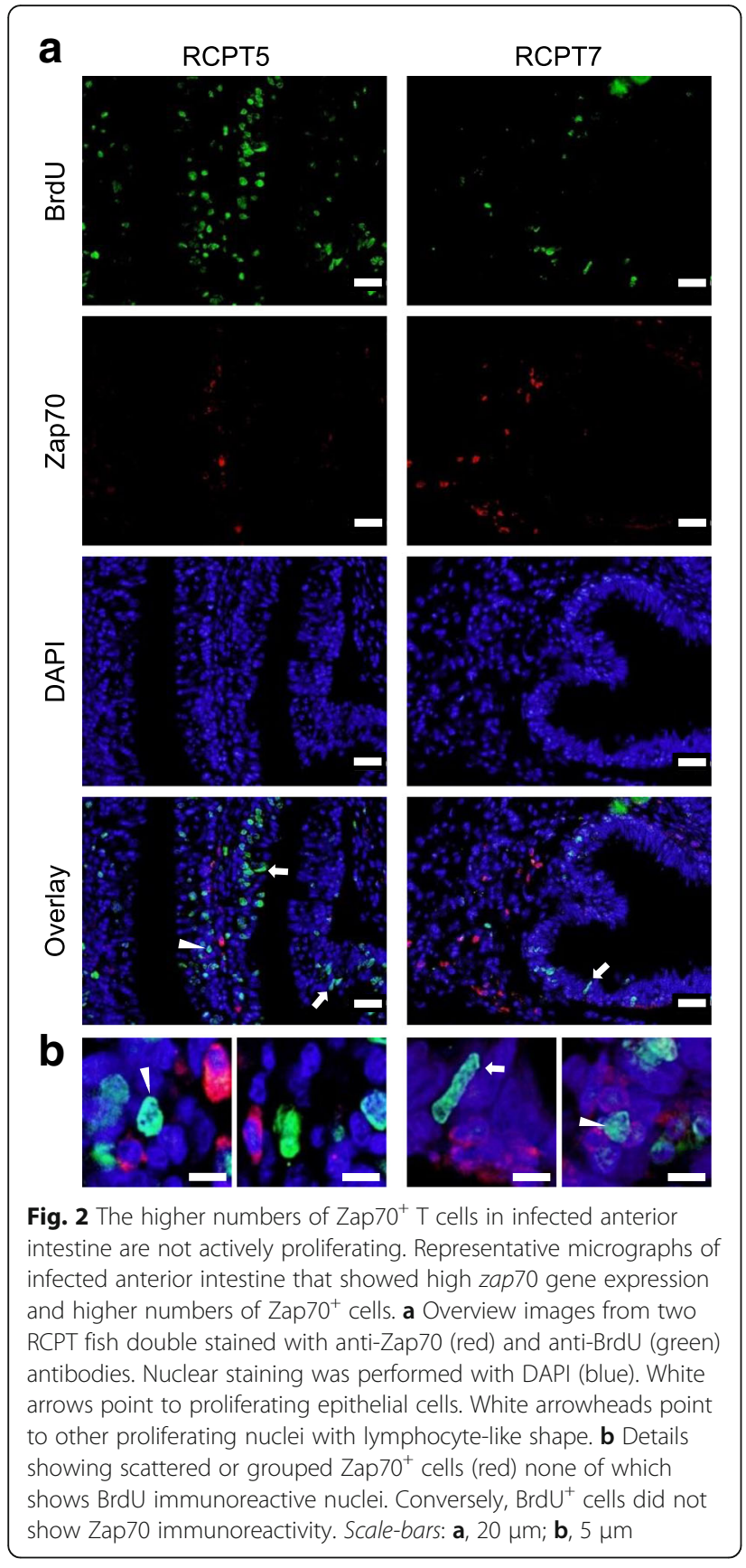

differ from what was observed in the previous analysis (Table 3). In head kidney, $\mathrm{RCPT}^{-}$fish showed significantly downregulated $c d 4-2$ expression (ANOVA: $\left.F_{(2,17)}=3.43, P=0.05\right)$, while in spleen $\mathrm{RCPT}^{-}$always displayed an intermediate phenotype in the differentially regulated genes. In the anterior intestine, $\mathrm{RCPT}^{-}$ fish showed a more specific phenotype with upregulation of $\mathrm{T}_{\mathrm{H}}\left(c d 4-1\right.$ (ANOVA: $\left.F_{(2,17)}=8.58, P=0.0027\right)$ and $c d 4-2$ (ANOVA: $\left.F_{(2,17)}=6.083, P=0.0102\right)$ ) and CTL $\left(c d 8 \alpha\right.$ (ANOVA: $\left.F_{(2,17)}=4.889, P=0.021\right)$ and $c d 8 \beta$ (ANOVA: $\left.F_{(2,17)}=4.504, P=0.027\right)$ ) receptors. $\mathrm{RCPT}^{-}$
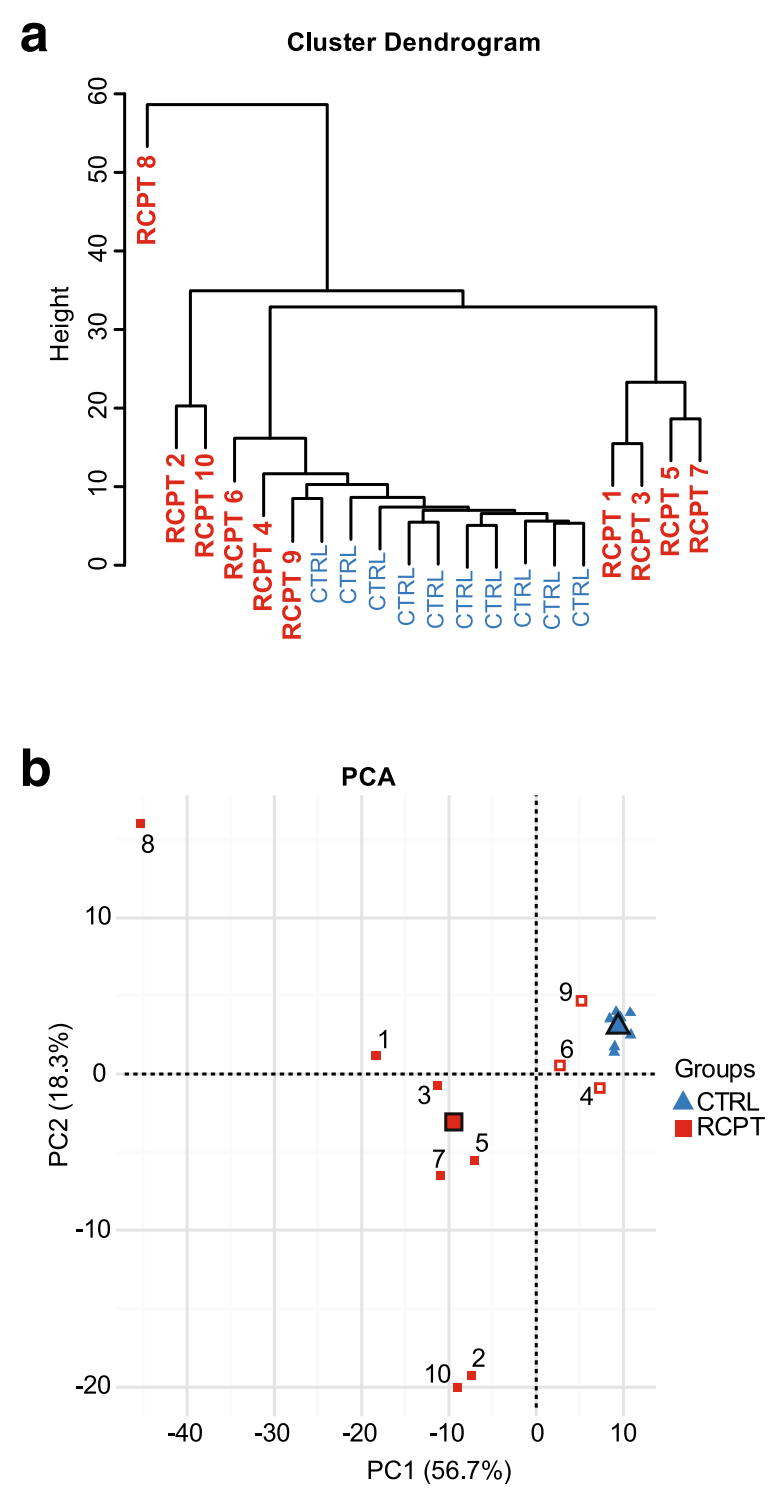

Fig. 3 Infection status correlates with differential clustering of recipient fish. a Hierarchical cluster analysis using individual expression values of the T cell signature molecules in all tissues of the 10 control (CTRL, blue) and 10 recipient (RCPT, red) fish. RCPT fish numbers correlate with the numbers in Table 2. b Principal components analysis constructed using individual expression values of the T cell signature molecules in all tissues of the 10 CTRL (blue triangles) and 10 RCPT (red squares) fish. Numbers correlate with the respective RCPT fish. Bigger symbols represent the centroids for each group. The recipient fish that clustered within the CTRL group in the hierarchical cluster are depicted in red and white squares. Numbers of the individual CTRL fish were removed for clarity

phenotype in posterior intestine was generally intermediate between CTRL and $\mathrm{RCPT}^{+}$groups, but had larger differences with the $\mathrm{RCPT}^{+}$group than with the CTRL group, explaining the clustering closer to the CTRL group in Fig. 4d. 

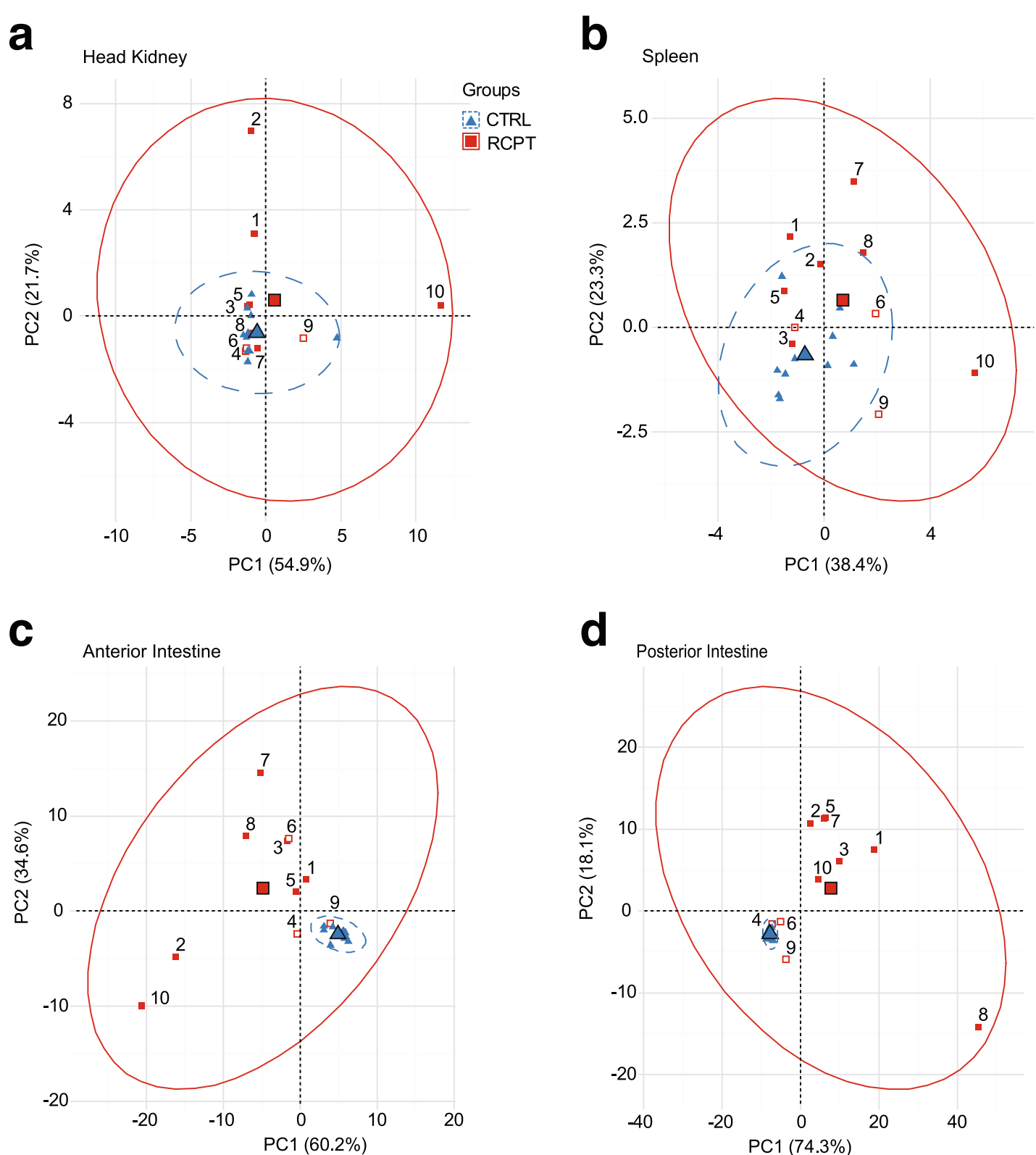

Fig. 4 Enteromyxum leei exposure elicits changes in the expression of T cell signature genes at the local level. Principal component analyses constructed using individual expression values of the T cell signature molecules in head kidney (a), spleen (b), anterior (c) and posterior intestine (d). Numbers correlate with the respective RCPT fish (red squares). Bigger symbols represent the centroids for each group's ellipse. The recipient fish that clustered within the CTRL group (blue triangles) in Fig. 3a are depicted in red and white squares. Numbers of the individual CTRL fish were removed for clarity

\section{Discussion}

The aim of the current study was to gain insights of the $\mathrm{T}$ cell response of gilthead sea bream upon infection with $E$. leei. Previous studies using this host-parasite model showed that E. leei modulated different leukocyte populations, both at a local and systemic level. It induced proliferation of leukocytes in head kidney with recruitment into intestines via blood circulation, a general increase in mast cells and depletion of acidophilic granulocytes [8]. $\operatorname{IgM}^{+} \mathrm{B}$ cells and secreted and membrane $\operatorname{Ig} M$ and $\operatorname{Ig} T$ transcripts increased in infected intestine [3, 4, present study]. The current results show an increased number of secreted $\operatorname{IgM}$ and $\operatorname{Ig} T$ transcripts in the target tissues of infected animals and point to the proliferation of $\operatorname{IgM}^{+}$and $\operatorname{IgT}^{+}$cells, supported by increased numbers of membrane $I g$ transcripts and increased expression of pax5, a marker for B cell differentiation $[25,28]$. Interestingly, in $\mathrm{RCPT}^{-}$fish, the B cell response was almost equal to that of CTRL fish (Fig. 5). To 

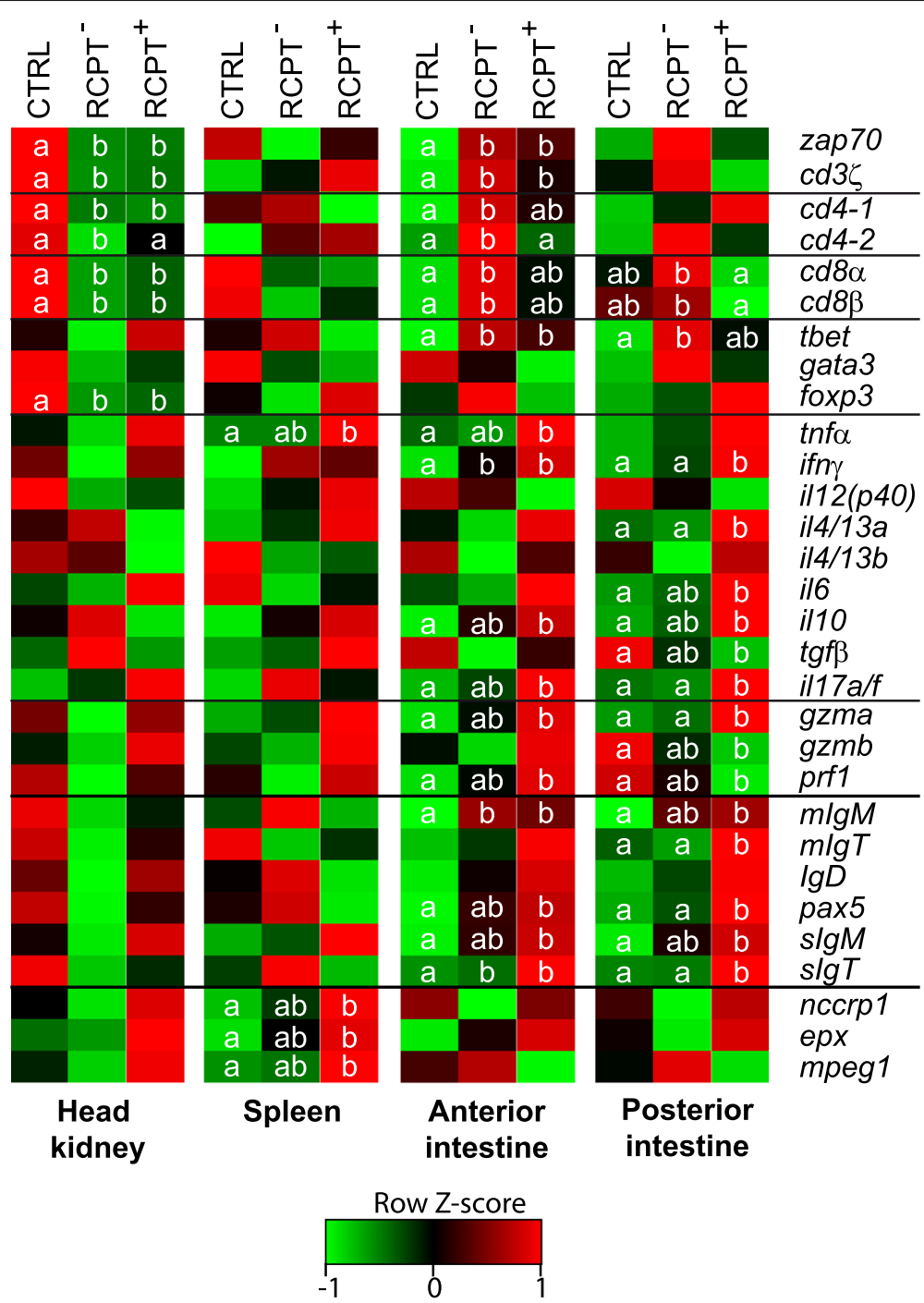

Fig. 5 Enteromyxum leei-exposed non-infected fish show an intermediate phenotype at a local level. Heatmaps depicting the differential expression of all studied genes in the different tissues. Average expression values of the 10 control unexposed (CTRL) fish, the 3 recipient (RCPT) fish that were negative for the parasite (RCPT $)$ and the 7 RCPT fish that scored positive for the parasite $\left(\mathrm{RCPT}^{+}\right)$were used to construct the heatmaps. Values are centred and scaled per row. Thus, the different colours show the standard deviations from the mean per row (row Z-score). Different letters indicate statistical differences in expression when comparing the three groups by ANOVA $(P<0.05)$

date, the $\mathrm{T}$ cell response in this host-parasite model has not been specifically studied.

The study of fish $\mathrm{T}$ cell responses has been hampered by the lack of specific antibodies and molecular tools. Nowadays, several $\mathrm{T}$ cell specific antibodies have been developed for a few fish species such as rainbow trout (Oncorhynchus mykiss), spotted green pufferfish (Tetraodon nigroviridis), ginbuna crucian carp (Carassius auratus langsdorfii) or Japanese pufferfish (Takifugu rubripes) [29-34] and some showed cross-reaction with close species [30]. In addition, $\mathrm{CD}^{+} \mathrm{T}$ cell lines have recently been established for common carp [35] and rainbow trout [32] and also CD4-transgenic zebrafish have been created [36]. Recent studies addressing the functional characterization of fish T cells subpopulations, point to a certain degree of conservation with mammals [21,37]. Regretfully, not many tools are available to study these cell populations outside salmonids and cyprinids. Consequently, we approached our research using transcriptomic tools and validated the observations with the available antibodies, aiming not to infer absolute conclusions, but to obtain hints to base future functional studies. A schematic summary of the results of this study is shown in Fig. 6 to facilitate the global overview of the responses in the different tissues, as discussed below.

Upon activation, the TCR transmits the signal via the CD3 complex. In teleost fish, three CD3 chains have been identified, $\mathrm{CD} 3 \gamma \delta, \mathrm{CD} 3 \varepsilon$ and $\mathrm{CD} 3 \zeta$, the later 


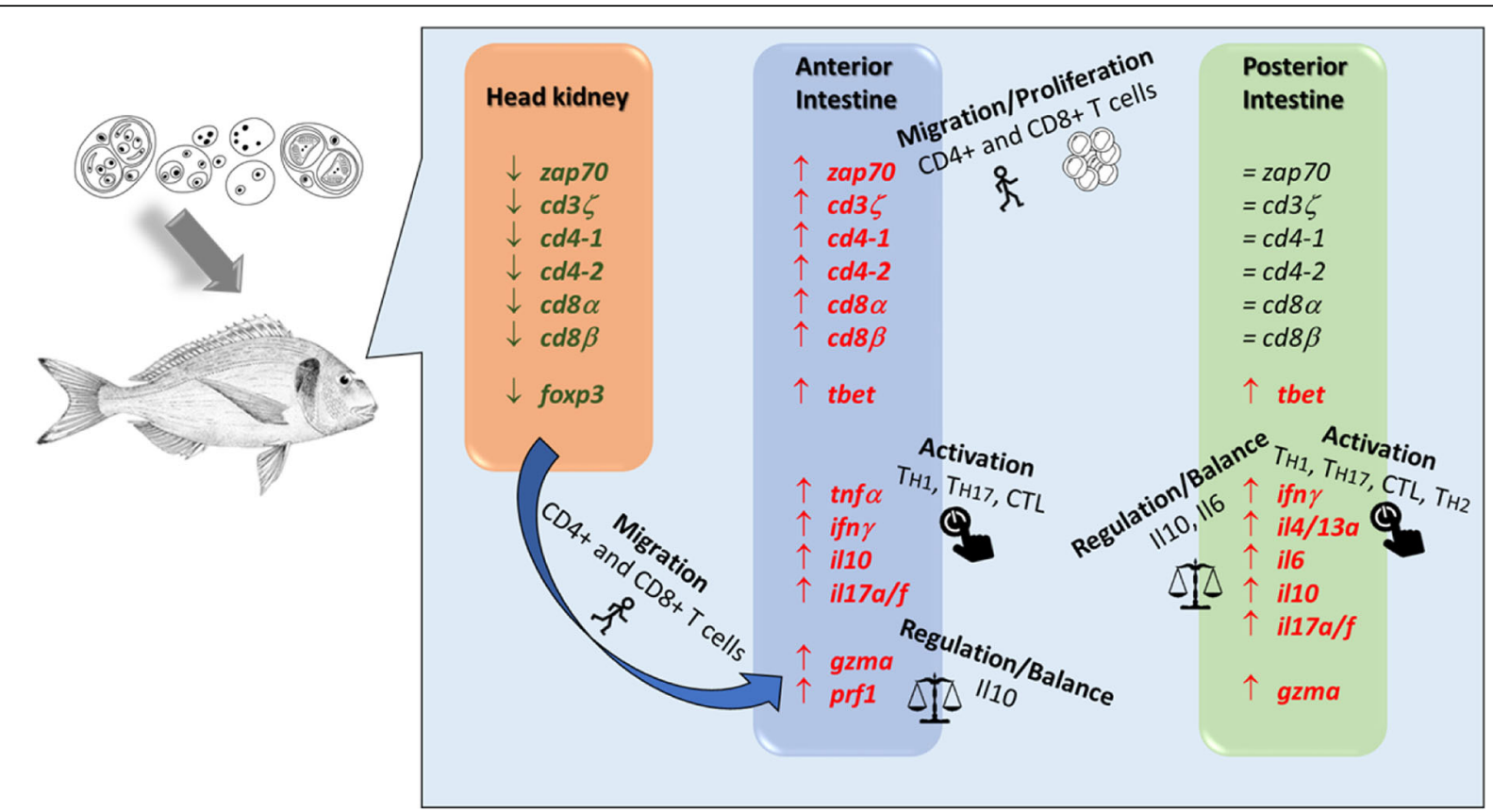

Fig. 6 Schematic summary of the PCR-array results on T cell signature molecules showing key signature genes and their expression changes in head kidney, anterior and posterior intestine of gilthead sea bream upon infection with Enteromyxum leei, including the hypothesis extracted from the results. Green and red represent significantly down- and upregulated genes, respectively, in RCPT fish. Genes indicated in black showed no significant changes

responsible for the recruitment and activation of the Zap70 kinase [19]. Hence, the CD3 chains and Zap70 are commonly used pan $\mathrm{T}$ cell markers both in mammals and fish $[21,25]$. In the present study, $c d 3 \zeta$ and zap70 expression levels were very consistent, being both up- or downregulated simultaneously. The expression of zap70 was also confirmed at protein level. High expression values for zap70 correlated with a higher number of Zap70 ${ }^{+}$cells in gilthead sea bream intestine. Zap70 cells had a morphology and tissue location consistent with intestinal intraepithelial T lymphocytes. E. leei exposure induced zap70 downregulation in head kidney and an upregulation in anterior intestine. The lower expression of $c d 4-1, c d 4-2, c d 8 \alpha$ and $c d 8 \beta$ in head kidney and the increased expression of the same genes in anterior intestine indicate that both $\mathrm{T}_{\mathrm{H}}$ cells and CTLs were modulated during the infection. Of note, the downregulation in head kidney was characterized by changes in pan T cell markers, $c d 4$ and $c d 8$ expression, whereas the expression of the effector cytokines and enzymes did not change. Changes in specific markers of effector phenotypes were only detected in the target tissue, where the parasite is located.

The increased expression of zap70 and higher number of Zap $70^{+}$cells in infected anterior intestine can be due to migration from lymphohaematopoietic tissues, local proliferation of $\mathrm{T}$ cells, or both. The reverse trend of expression of pan $\mathrm{T}$ cell markers and receptors between head kidney and anterior intestine in infected fish seems to indicate migration. However, further functional studies should be conducted to verify this hypothesis. Adoptive cell transfer has been successfully used in T cell studies in teleosts $[38,39]$, but no clonal lines of gilthead sea bream are available. On the other hand, an in vivo proliferation assay on gilthead sea bream intestine by the use of BrdU immunostaining has recently been optimized in our group [26]. This study showed that, upon infection with E. leei, intestinal epithelial cells and lymphocyte-like cells showed increased proliferation when compared to control fish. However, in the current study, when double staining with the Zap70 antibody was performed, none of the Zap70 cells had a BrdU immunoreactive nucleus. These results indicate that, at least in the last 24 hours, intestinal Zap $70^{+}$cells were not proliferating. Thus, with the current tools available for gilthead sea bream, we have more evidence pointing towards migration of $\mathrm{T}$ cells to the target organ than to in situ proliferation. Time-course studies and migration assays should be conducted in the future to solve this question.

Teleosts have two $c d 4$ genes that are structural orthologues of the mammalian CD4. Teleost $c d 4-1$ has four Ig domains like the one from tetrapods, while $c d 4-2$ has two Ig domains and is believed to be a reminiscent of the primordial gene that gave rise to $c d 4$ and lag-3 by tandem duplication. Both $c d 4$ genes contain the canonical Lck association motif essential for the initiation of 
the $T$ cell activation cascade $[19,40,41]$. In rainbow trout, most $\mathrm{T}_{\mathrm{H}}$ lymphocytes showed co-expression of both $c d 4-1$ and $c d 4-2$ in their membrane, while a small uncharacterized lymphocyte population appeared $c d 4-2$ single positive [29]. The same study showed that a significant myeloid population expressed $c d 4-1$, just like monocyte/macrophages from rats and humans [42]. Thus, the expression of the four-domain $c d 4-1$ gene should not be directly linked to $\mathrm{T}_{\mathrm{H}}$ responses in the $\mathrm{ab}-$ sence of other markers. The results in the current study show a parallel regulation of $c d 4-1$ and $c d 4-2$ in head kidney (downregulation) and anterior intestine (upregulation) which, together with the pan $\mathrm{T}$ cell markers information and unresponsiveness of the macrophage specific mpeg-1 [43], indicate that E. leei is regulating $\mathrm{T}_{\mathrm{H}}$ responses in these organs. The highest expression of both $c d 4$ genes in anterior intestine was found in exposed, but non-infected fish $\left(\mathrm{RCPT}^{-}\right)$, pointing towards a higher number of $\mathrm{T}_{\mathrm{H}}$ cells in these animals.

When naive $\mathrm{CD}^{+} \mathrm{T}$ cells become activated, they proliferate and differentiate into distinct $\mathrm{T}_{\mathrm{H}}$ subsets [44]. Each subset expresses a battery of signature genes that can provide important insights on the populations. However, the expression of certain groups of genes is not definitive due to overlapping. Different leukocytes, and even different $\mathrm{T}$ cell subsets, can express certain genes in common. Therefore, differences are better assessed by up- or downregulation of a battery of genes, more than by restricted expression of single molecules [45]. In mammals, $\mathrm{T}_{\mathrm{H} 1}$ activation is initiated by IL12 and IFN $\gamma$, Tbet being the master regulator of this subset. Tbet expression is not exclusive for $\mathrm{T}_{\mathrm{H} 1}$ cells, it is also expressed in IFN $\gamma$ stimulated monocytes and dendritic cells, B cells, NK cells and CTLs. Unlike Tbet, the $\mathrm{T}_{\mathrm{H} 2}$ master regulator GATA3 is already expressed in naïve $\mathrm{CD}^{+} \mathrm{T}$ cells $[16,46,47]$. Mucosal tissues, due to their constant exposure to external antigens, have been described as $\mathrm{T}_{\mathrm{H} 2}$-skewed. Mucosal regulation of $\mathrm{T}_{\mathrm{H} 2}$ responses is key to maintain balance of host immune homeostasis and defence against pathogens [48]. In fish mucosal tissues, the relative expression of gata3 is higher than that of tbet $[49,50]$. However, when considering the ratio of the effector molecules (il4/13a and if $n \gamma$ ) trout gills and skin, but not intestines, showed this $\mathrm{T}_{\mathrm{H} 2}$ skewing [51]. In the current study, the ratio $\mathrm{T}_{\mathrm{H} 1} /$ $\mathrm{T}_{\mathrm{H} 2}$ in CTRL fish, calculated in two different ways (tbet / gata3 and ifny / il4/13a) [51, 52], showed that $\mathrm{T}_{\mathrm{H} 1}$ profiles were more dominant in head kidney and spleen, whereas intestine was more skewed to the prototypical $\mathrm{T}_{\mathrm{H} 2}$ profile of mucosal tissues. Thus, in our model, gilthead sea bream intestines clearly showed this $\mathrm{T}_{\mathrm{H} 2}$ profile typically related to mucosal tissues.

The current results suggest that the increase in $T_{H}$ cells induced by the parasitic infection in gilthead sea bream anterior intestine is due to activation of $\mathrm{T}_{\mathrm{H} 1}$ and $\mathrm{T}_{\mathrm{H} 17}$ profiles. This is supported by the significant upregulation of tbet, ifn $\gamma$, and ill7a/f, and the higher number of Tbet $^{+}$cells. In posterior intestine, a mixed profile with the additional upregulation of il6 and il4/13a $\left(\mathrm{T}_{\mathrm{H} 2}\right)$ was detected. However, in RCPT posterior intestine upregulation of pan $\mathrm{T}$ cell markers, $c d 4$ or $c d 8$ was not observed. One explanation for this could be that the response in this segment is not characterized by increased cell numbers nor proliferation, but more by activation of resident cells, as opposed to the hypothesized migration in anterior intestines discussed above. In rainbow trout, infections with the myxozoan parasite Tetracapsuloides bryosalmonae induced an increase of tbet and ifny expression in the kidney, the target organ for this parasite. In the same study, almost no change was detected for gata3 [49]. A similar study in T. bryosalmonae-infected trout, showed upregulation of il10, il6, ifn $\gamma$, tbet and $\mathrm{T}_{\mathrm{H} 17}$ cytokines in trunk kidney [53].

Mammalian IL17A and IL17F, and the fish homologue, Il17a/f, can be expressed by many cells, but their major producers in vivo are $\mathrm{T}_{\mathrm{H} 17}$ cells [20]. Our results show that $i l 17 a / f$ is among the most strongly upregulated genes in parasitized intestines. This is in accordance with what was detected in common carp during infections with the blood parasite Trypanosoma carassii, which induced a $\mathrm{T}_{\mathrm{H} 17}$ profile with upregulation of $i l 17 a /$ $f 2$ [54]. In mammals, IL6 is known to have a pivotal role in switching the immune response from tolerance to inflammation by increasing the expression of $R O R \gamma t$ $\left(\mathrm{T}_{\mathrm{H} 17}\right)$ and inhibiting FOXP3 $\left(\mathrm{T}_{\mathrm{reg}}\right)$. IL6 skews the $\mathrm{T}_{\mathrm{H} 1} /$ $\mathrm{T}_{\mathrm{H} 2}$ balance towards $\mathrm{T}_{\mathrm{H} 2}$ by directly inducing expression of IL4 [55]. However, some studies showed that both IL6 and TGF $\beta$ are required for $\mathrm{T}_{\mathrm{H} 17}$ development [56]. In the current study, il6 was upregulated only in the posterior intestine, whereas il17a/f was upregulated in both intestinal segments. This higher expression of il 6 in the posterior intestine was concurrent with a higher expression of $i l 4 / 13 a$ and downregulation of $\operatorname{tgf} \beta$ supporting a role for Il6 in $\mathrm{T}_{\mathrm{H} 2}$ development in this model.

Mammalian $\mathrm{T}_{\text {regs }}$ are $\mathrm{CD} 4^{+} / \mathrm{CD} 25^{+} / \mathrm{FOXP}^{+}$cells with immunosuppressive activities mainly due to their production of the anti-inflammatory cytokines TGF $\beta$ and IL10 [18]. Immunosuppressive CD4- $2^{+} / \mathrm{CD} 25^{+} / \mathrm{Foxp}^{+}$ cells have been functionally characterized in tetraodon, demonstrating the existence of $\mathrm{T}_{\text {reg }}$ homologues in teleosts [34]. The expression profiles found in our study do not support major changes in the $\mathrm{T}_{\text {reg }}$ population, although the expression of illo was clearly induced in spleen and intestine of RCPT fish. IL10 is a pleiotropic regulatory cytokine that can be produced by many different cell types and is crucial to maintain intestinal tolerance [57]. In fact, different common carp isolated leukocyte populations showed the ability to express il10 
[58]. Thus, the increased expression of il10 detected in our study is most likely due to a different cell population than $\mathrm{T}_{\text {regs }}$ and is probably aimed to control the damage that excessive inflammation can cause to host tissues. Upregulation of $i l 10$ and $i l 6$ has already been described in the posterior intestine of E. leei-infected gilthead sea bream [9]. The latter study linked the upregulation of these two genes to an anti-inflammatory profile, although the expression of ifny and illia/f, pro-inflammatory cytokines significantly upregulated in the current study, was not studied then. The expression of $i l 10$ and $i l 6$ was significantly upregulated together with ifny, ill7alf and il4/13a in $\mathrm{RCPT}^{+}$fish intestines. In $\mathrm{RCPT}^{-}$(exposed, non-infected) fish, these cytokines returned to control expression levels. These new findings indicate that the increased expression of il6 and $i l 10$ are more likely linked to limit, but maintain, an inflammatory response against the parasite. These results corroborate previous findings in other myxozoan infections, where a dysregulated $\mathrm{T}$ cell response characterized by $\mathrm{T}_{\mathrm{H} 1}$ and $\mathrm{T}_{\mathrm{H} 17}$ profiles, together with upregulation of anti-inflammatory/regulatory cytokines (il10 and il6) and increased expression of immunoglobulins (mainly secreted) was found [53]. Of note, although the latter and present studies used different fish species and different myxozoan parasites with different target tissues, both models elicited very similar responses.

The prototypical cytotoxic activity of mammalian CTLs has also been described in fish [59-62]. Similar to what was found for $T_{H}$ cells, our results showed upregulation of both $c d 8$ genes in the anterior intestine, which correlated with downregulation in head kidney, upon infection. CTL activity in E. leei-infected anterior intestine was supported by a significant increase in gzma and prf1 expression. In all vertebrates, CTLs and NK cells are known to express several receptors, transcription factors and effector molecules in common [63]. Nevertheless, our results show that the increased $c d 8$ expression detected is not correlated with changes in expression of nccrp1, a receptor needed for recognition of target cells expressed in natural cytotoxic cells (NCC), the teleost NK equivalents [64]. CTLs also express Tbet and IFNY [13], thus the increased expression of these molecules can also be attributed to such cell population. In any case, E. leei infection clearly induced a type 1 immune response in the target tissue. Activated teleost CTLs have been described to be major producers of Ifn $\gamma$, granzymes and perforin [65]. In the current study, gzma was one of the most upregulated genes in both intestinal segments upon E. leei infection; and while prf1 showed the same trend in anterior intestine, gzmb did not. Mammalian studies on the dynamics of expression of effector molecules in CTLs showed that $\mathrm{GzmA}^{+} / \mathrm{GzmB}^{-}$cells are detected earlier than $\mathrm{GzmA}^{+} / \mathrm{GzmB}^{+}$cells. In addition, GzmA has trypsin like activity cleaving after the basic residues arginine and lysine, whereas $\mathrm{GzmB}$ cleaves after aspartic acid residues [66]. Thus, the expression profile detected in our study could indicate (i) a time-point situation where only $\mathrm{Gzma}^{+} / \mathrm{Gzmb}^{-}$cells are present; (ii) a specific regulation where only trypsin like activity is required; or (iii) a dysregulation of the CTL response induced by the parasite. Of note, $\mathrm{RCPT}^{-}$fish showed higher levels of $c d 8$ expression in intestine, whereas the expression of the effector molecules was only higher in $\mathrm{RCPT}^{+}$fish. Thus, we hypothesize that fish with more $\mathrm{CD}^{+}$cells or with higher levels of activation of this subtype have more chances to successfully avoid or clear the infection. A recent study in Atlantic salmon (Salmo salar) infected with the myxozoan Kudoa thyrsites showed that CTLs are key for resolution of infection and protection against reinfection [67].

CTLs are classically considered to specifically target virus-infected, tumor and allogenic cells. However, recent studies demonstrated that their role expands to the ability of directly killing microbial pathogens, including extracellular parasites [68]. In fact, cell cytotoxic activity has already been described as one of the main immune mechanisms involved in gilthead sea bream immune response to E. leei [69]. The possibility that the infection method used (anal intubation of infected intestinal scrapings) could elicit a CTL reaction against the allogenic cells present in the inoculum could raise some concern. In common carp, anal administration of allogenic cells induced specific cell-mediated cytotoxicity which peaked seven days after immunization but, in the absence of re-exposure to the antigen, returned to control levels after 20 days [70]. Our observations, performed ten weeks after inoculation, should only be due to the parasitic infection, which actually establishes and progresses in the intestine, while the allogenic cells are rapidly eliminated. Supporting this, infections by cohabitation with $E$. leei-infected fish, also elicited cytotoxic cell activity [69].

Taken together, the analysis of the expression levels of the genes selected for this study effectively separated infected $\left(\mathrm{RCPT}^{+}\right)$from non-infected $\left(\mathrm{RCPT}^{-}\right.$and CTRL) fish. It is a fact that not one immune response is uniquely represented by a single $\mathrm{T}$ cell subset, but a particular phenotype could be overrepresented. E. leei seems to have induced the migration of $\mathrm{T}$ cells from head kidney to the anterior intestine and type $1\left(\mathrm{~T}_{\mathrm{H} 1}\right.$ and $\mathrm{CTL}$ ) and $\mathrm{T}_{\mathrm{H} 17}$ profiles in both intestinal segments. The higher expression of regulatory cytokines is probably balancing these inflammatory profiles to avoid damage (Fig. 6). By using the anal intubation route of infection, we assured that all RCPT fish were exposed to similar amounts of parasite at the same time. Moreover, all individuals from the RCPT group showed infection signs based on their biometrical parameters. 
This indicates that the $30 \%$ of fish that were negative for the parasite at the final sampling $\left(\mathrm{RCPT}^{-}\right)$, had successfully avoided parasite infection or had recovered from an initially established infection that did not progress. Interestingly, the expression profile of these exposed, but non-infected fish was more similar to the control than to the infected fish. A similar intermediate phenotype has been previously described using a massive analysis approach [71], supporting the current findings. This was more evident at the intestinal level, particularly in the posterior intestine, and we hypothesize that an effective and regulated CTL response is essential for the clearance of the parasite. Differential gene expression profiles between $\mathrm{RCPT}^{+}$and $\mathrm{RCPT}^{-}$fish, particularly in the intestine, have already been described for this infection model $[71,72]$. One of these studies showed that Ifn-stimulated genes were specifically upregulated in $\mathrm{RCPT}^{-}$animals [71], but the expression of ifny was never directly measured. Collectively, all results indicate that a type 1 response at the site of infection is needed to face and overcome this parasite.

There are still many unexplored facts to be addressed in future studies. For example, the sequences for $i l 2$, important $\mathrm{T}$ cell growth factor, or il21 and roryt, effector cytokine and master regulator of $\mathrm{T}_{\mathrm{H} 17}$ responses [20], were not found in the currently available genomic and transcriptomic data of gilthead sea bream and were consequently not studied. In addition, the existence of different isoforms for duplicated genes, so common in teleosts [73], was not detected with the current genomic data, but should not be discarded until more information is available. For instance, in the evolutionarily close European sea bass, two il4/13a isoforms have been described [74], and our preliminary analyses point to a similar event in gilthead sea bream that requires further study. The development of specific antibodies is also crucial to precisely define cell subtypes and functionally characterize them. Nonetheless, this study provides important clues on the gilthead sea bream intestinal $\mathrm{T}$ cell responses and can serve as a basis to better understand the response against this important parasite in order to establish effective preventive or palliative measures.

\section{Conclusions}

The results of the present study evidence a clear modulation of $\mathrm{T}$ cell responses in gilthead sea bream upon infection with $E$. leei. T cells appear to migrate from head kidney to the site of infection where they become activated. Type 1 responses are the most represented at a local level and the high expression of regulatory cytokines keeps this inflammatory profile in balance. The global analysis of these $\mathrm{T}$ cell markers in the intestine can provide information of their infection status.

\section{Additional files}

Additional file 1: Table S1. Primers used in the study. (PDF $458 \mathrm{~kb}$ )

Additional file 2: Table S2. Gene expression data relative to $\beta$-actin for each individual control (CTRL) and recipient (RCPT) fish used in the study. (PDF $501 \mathrm{~kb}$ )

\begin{abstract}
Abbreviations
BrdU: Bromodeoxyuridine; CTL: Cytotoxic T lymphocyte; CTRL: Control/ unexposed; Gzm: Granzyme; Ifn: Interferon; Ig: Immunoglobulin; IL: Interleukin; NCC: Non-specific cytotoxic cell; NK: Natural killer; p.i.: Postintubation; RCPT: Recipient/exposed; RCPT': Recipient negative for parasite presence; $\mathrm{RCPT}^{+}$: Recipient positive for parasite presence; SEM: Standard error of the mean; TCR: T cell receptor; TGF $\beta$ : Transforming growth factor beta; $\mathrm{T}_{\mathrm{H}}$ : Helper $\mathrm{T}$ cell; $\mathrm{T}_{\text {reg: }}$ : Regulatory $\mathrm{T}$ cell
\end{abstract}

\section{Acknowledgements}

The authors thank J. Monfort and L. Rodríguez for histological processing, M.A. González for technical assistance with gene expression analyses and I. Vicente for technical assistance with fish husbandry and sampling at IATS.

\section{Funding}

This work has been carried out with financial support from the Spanish MINECO under project AGL2013-48560-R. Additional funding was provided by the European Union, through the Horizon H2020 research and innovation programme under grant agreement 634429 (ParaFishControl). This publication reflects only the authors' view and the European Union cannot be held responsible for any use that may be made of the information contained herein. Further support was provided by Generalitat Valenciana (PROMETEOII/2014/085). MCP was contracted under CSIC PIE project no. 201740E013 and MINECO FPDI-2013-15741, and IE under APOSTD/2016/037 grant by the "Generalitat Valenciana". We acknowledge support of the publication fee by the CSIC Open Access Publication Support Initiative through its Unit of Information Resources for Research (URICI).

\section{Availability of data and materials}

All data generated by this study are included in the article and its additional files.

\section{Authors' contributions}

MCP, JPS and ASB conceived and planned the experiments. IE, RdP, APS and MCP performed the experimental infection, animal care and obtained and processed the samples. IE optimized the BrdU injection and staining protocol. ASB performed the parasite histological scoring. JACG and MCP performed the in silico analyses of the sequences identifying, cleaning and uploading the data to public databases and designing and optimizing the primers. MCP and ASB wrote the manuscript. All authors read and approved the final manuscript.

\section{Ethics approval}

Animals were kept according to the Guidelines of the European Union Council (Directive 2010/63/EU) and the Spanish RD 53/2013. All efforts were made to minimize suffering of the fish used for the experiments in accordance with national (Royal Decree RD1201/2005, for the protection of animals used in scientific experiments) and the current European Union legislation (86/609/EU).

\section{Consent for publication}

Not applicable.

\section{Competing interests}

The authors declare that they have no competing interests.

\section{Publisher's Note}

Springer Nature remains neutral with regard to jurisdictional claims in published maps and institutional affiliations. 


\section{Author details}

${ }^{1}$ Fish Pathology Group, Institute of Aquaculture Torre de la Sal (IATS-CSIC), Ribera de Cabanes, Castellón, Spain. ${ }^{2}$ Nutrigenomics and Fish Growth Endocrinology Group, Institute of Aquaculture Torre de la Sal (IATS-CSIC), Ribera de Cabanes, Castellón, Spain.

\section{Received: 5 April 2018 Accepted: 9 July 2018}

Published online: 31 July 2018

\section{References}

1. Food and Agriculture Organization of the United Nations. 2005-2018. Cultured Aquatic Species Information Programme. Sparus aurata. Rome: FAO Fisheries and Aquaculture Department; 2005. http://www.fao.org/ fishery/culturedspecies/Sparus_aurata/en.

2. Okamura B, Gruhl A, Bartholomew JL. An introduction to myxozoan evolution, ecology and development. In: Okamura B, Gruhl A, Bartholomew $J$, editors. Myxozoan evolution, ecology and development. Switzerland: Springer International Publishing; 2015. p. 1-22.

3. Estensoro I, Redondo MJ, Alvarez-Pellitero P, Sitjà-Bobadilla A. Novel horizontal transmission route for Enteromyxum leei (Myxozoa) by anal intubation of gilthead sea bream Sparus aurata. Dis Aquat Organ. 2010; 92:51-8.

4. Sitjà-Bobadilla A, Palenzuela O. Enteromyxum species. In: Woo P, Buchmann $\mathrm{K}$, editors. Fish parasites: pathobiology and protection. Wallingford: $\mathrm{CABl}$; 2012. p. 163-76.

5. Sitjà-Bobadilla A, Schmidt-Posthaus H, Wahli T, Holland JW, Secombes CJ. Fish immune responses to Myxozoa. In: Okamura B, Gruhl A, Bartholomew $J$, editors. Myxozoan evolution, ecology and development. Switzerland: Springer International Publishing; 2015. p. 253-80.

6. Estensoro I, Calduch-Giner JA, Kaushik S, Pérez-Sánchez J, Sitjà-Bobadilla A. Modulation of the $\lg \mathrm{M}$ gene expression and $\lg \mathrm{M}$ immunoreactive cell distribution by the nutritional background in gilthead sea bream (Sparus aurata) challenged with Enteromyxum leei (Myxozoa). Fish Shellfish Immunol. 2012;33:401-10.

7. Piazzon MC, Galindo-Villegas J, Pereiro P, Estensoro I, Calduch-Giner JA, Gomez-Casado E, et al. Differential modulation of IgT and IgM upon parasitic, bacterial, viral, and dietary challenges in a Perciform fish. Front Immunol. 2016;7:637.

8. Estensoro I, Mulero I, Redondo MJ, Alvarez-Pellitero P, Mulero V, SitjàBobadilla A. Modulation of leukocytic populations of gilthead sea bream (Sparus aurata) by the intestinal parasite Enteromyxum leei (Myxozoa: Myxosporea). Parasitology. 2014;141:425-40.

9. Pérez-Cordón G, Estensoro I, Benedito-Palos L, Calduch-Giner JA, SitjàBobadilla A, Pérez-Sánchez J. Interleukin gene expression is strongly modulated at the local level in a fish-parasite model. Fish Shellfish Immunol. 2014:37:201-8

10. Vaccio M, Ciucci T, Bosselut R. 200 million thymocytes and I: a beginner's survival guide to T cell development. Methods Mol Biol. 2016;1323:3-21.

11. Barry M, Bleackley RC. Cytotoxic T lymphocytes: all roads lead to death. Nat Rev Immunol. 2002;2:401-9.

12. Strasser A, Jost PJ, Nagata $S$. The many roles of FAS receptor signaling in the immune system. Immunity. 2009;30:180-92.

13. Russ B, Prier J, Rao S, Turner S. T cell immunity as a tool for studying epigenetic regulation of cellular differentiation. Front Genet. 2013;4:218.

14. Kleinewietfeld M, Hafler DA. The plasticity of human Treg and Th17 cells and its role in autoimmunity. Semin Immunol. 2013;25:305-12.

15. O'Shea JJ, Paul WE. Mechanisms underlying lineage commitment and plasticity of helper CD4+ T cells. Sci. 2010;327:1098-102.

16. Kanhere A, Hertweck A, Bhatia U, Gokmen MR, Perucha E, Jackson I, et al. T-bet and GATA3 orchestrate Th1 and Th2 differentiation through lineagespecific targeting of distal regulatory elements. Nat Commun. 2012;3:1268

17. Ruan Q, Kameswaran V, Zhang Y, Zheng S, Sun J, Wang J, et al. The Th17 immune response is controlled by the Rel-RORgamma-RORgamma $T$ transcriptional axis. J Exp Med. 2011;208:2321-33.

18. Shevach EM. Mechanisms of foxp3+ T regulatory cell-mediated suppression. Immunity. 2009;30:636-45.

19. Laing KJ, Hansen JD. Fish T cells: Recent advances through genomics. Dev Comp Immunol. 2011;35:1282-95.

20. Wang T, Secombes CJ. The cytokine networks of adaptive immunity in fish. Fish Shellfish Immunol. 2013;35:1703-18.

21. Nakanishi T, Shibasaki Y, Matsuura Y. T cells in fish. Biology (Basel). 2015:4:640-63.
22. Palenzuela $\mathrm{O}$, Bartholomew JL. Molecular tools for the diagnosis of Ceratomyxa shasta (Myxozoa). In: Cunningham CO, editor. Molecular diagnosis of salmonid diseases. New York: Springer-Verlag; 2002. p. 285-98.

23. Calduch-Giner JA, Bermejo-Nogales A, Benedito-Palos L, Estensoro I, Ballester-Lozano G, Sitjà-Bobadilla A, et al. Deep sequencing for de novo construction of a marine fish (Sparus aurata) transcriptome database with a large coverage of protein-coding transcripts. BMC Genomics. 2013;14:178.

24. Livak KJ, Schmittgen TD. Analysis of relative gene expression data using real-time quantitative PCR and the 2(-Delta Delta C(T)) Method. Methods. 2001;25:402-8.

25. Piazzon MC, Savelkoul HFJ, Pietretti D, Wiegertjes GF, Forlenza M. Carp ॥10 has anti-inflammatory activities on phagocytes, promotes proliferation of memory $T$ cells, and regulates B cell differentiation and antibody secretion. J Immunol. 2015;194:187-99.

26. Estensoro I, Pérez-Cordón G, Sitjà-Bobadilla A, Piazzon MC. Bromodeoxyuridine DNA labelling reveals host and parasite proliferation in a fish-myxozoan model. J Fish Dis. 2018;41:651-62.

27. R Core Team. R: A language and environment for statistical computing. Vienna: R Foundation for Statistical Computing; 2014.

28. Zwollo P, Haines A, Rosato P, Gumulak-Smith J. Molecular and cellular analysis of B-cell populations in the rainbow trout using Pax5 and immunoglobulin markers. Dev Comp Immunol. 2008;32:1482-96.

29. Takizawa F, Magadan S, Parra D, Xu Z, Korytar T, Boudinot P, et al. Novel teleost CD4-bearing cell populations provide insights into the evolutionary origins and primordial roles of CD4+ lymphocytes and CD4+ macrophages. J Immunol. 2016;196:4522-35.

30. Miyazawa R, Matsuura Y, Shibasaki Y, Imamura S, Nakanishi T. Cross-reactivity of monoclonal antibodies against CD4-1 and CD8a of ginbuna crucian carp with lymphocytes of zebrafish and other cyprinid species. Dev Comp Immunol. 2018;80:15-23.

31. Boardman T, Warner C, Ramirez-Gomez F, Matrisciano J, Bromage E. Characterization of an anti-rainbow trout (Oncorhynchus mykiss) CD3ع monoclonal antibody. Vet Immunol Immunopathol. 2012;145:511-5.

32. Maisey K, Montero R, Corripio-Miyar Y, Toro-Ascuy D, Valenzuela B, ReyesCerpa $\mathrm{S}$, et al. Isolation and characterization of salmonid CD4+ T cells. J Immunol. 2016;196:4150-63.

33. Kono $\mathrm{T}$, Korenaga $\mathrm{H}$. Cytokine gene expression in CD4 positive cells of the Japanese pufferfish, Takifugu rubripes. PLoS One. 2013;8:e66364.

34. Wen Y, Fang W, Xiang LX, Pan RL, Shao JZ. Identification of Treg-like cells in Tetraodon: insight into the origin of regulatory $T$ subsets during early vertebrate evolution. Cell Mol Life Sci. 2011;68:2615-26.

35. Yamaguchi T, Katakura F, Someya K, Dijkstra JM, Moritomo T, Nakanishi T. Clonal growth of carp (Cyprinus carpio) T cells in vitro: long-term proliferation of Th2-like cells. Fish Shellfish Immunol. 2013;34:433-42.

36. Dee CT, Nagaraju RT, Athanasiadis El, Gray C, Fernandez del Ama L, Johnston SA, et al. CD4-Transgenic zebrafish reveal tissue-resident Th2- and regulatory $\mathrm{T}$ cell-like populations and diverse mononuclear phagocytes. J Immunol. 2016;197:3520-30.

37. Toda H, Saito Y, Koike T, Takizawa F, Araki K, Yabu T, et al. Conservation of characteristics and functions of CD4 positive lymphocytes in a teleost fish. Dev Comp Immunol. 2011;35:650-60.

38. Somamoto T, Kondo M, Nakanishi T, Nakao M. Helper function of CD4(+) lymphocytes in antiviral immunity in ginbuna crucian carp, Carassius auratus langsdorfii. Dev Comp Immunol. 2014;44:111-5.

39. Utke K, Kock H, Schuetze H, Bergmann SM, Lorenzen N, Einer-Jensen K, et al. Cell-mediated immune responses in rainbow trout after DNA immunization against the viral hemorrhagic septicemia virus. Dev Comp Immunol. 2008;32:239-52.

40. Castro R, Bernard D, Lefranc MP, Six A, Benmansour A, Boudinot P. T cell diversity and TcR repertoires in teleost fish. Fish Shellfish Immunol. 2011;31:644-54.

41. Laing KJ, Zou JJ, Purcell MK, Phillips R, Secombes CJ, Hansen JD. Evolution of the CD4 family: teleost fish possess two divergent forms of CD4 in addition to lymphocyte activation gene-3. J Immunol. 2006; 177:3939-51.

42. Gordon S, Taylor PR. Monocyte and macrophage heterogeneity. Nat Rev Immunol. 2005;5:953-64.

43. Spilsbury K, O'Mara MA, Wu WM, Rowe PB, Symonds G, Takayama Y. Isolation of a novel macrophage-specific gene by differential cDNA analysis. Blood. 1995;85:1620-9.

44. Yamane H, Paul WE. Early signaling events that underlie fate decisions of naive CD4(+) T cells toward distinct T-helper cell subsets. Immunol Rev. 2013;252:12-23. 
45. Chtanova T, Newton R, Liu SM, Weininger L, Young TR, Silva DG, et al. Identification of $T$ cell-restricted genes, and signatures for different $T$ cell responses, using a comprehensive collection of microarray datasets. J Immunol. 2005;175:7837-47.

46. Mohamed R, Lord GM. T-bet as a key regulator of mucosal immunity. Immunology. 2016;147:367-76.

47. Lazarevic V, Glimcher LH, Lord GM. T-bet: a bridge between innate and adaptive immunity. Nat Rev Immunol. 2013;13:777-89.

48. Bulek K, Swaidani S, Aronica M, Li X. Epithelium: the interplay between innate and Th2 immunity. Immunol Cell Biol. 2010;88:257-68.

49. Wang T, Holland JW, Martin SAM, Secombes CJ. Sequence and expression analysis of two $T$ helper master transcription factors, T-bet and GATA3, in rainbow trout Oncorhynchus mykiss and analysis of their expression during bacterial and parasitic infection. Fish Shellfish Immunol. 2010:29:705-15.

50. Tafalla C, Leal E, Yamaguchi T, Fischer U. T cell immunity in the teleost digestive tract. Dev Comp Immunol. 2016;64:167-77.

51. Takizawa F, Koppang EO, Ohtani M, Nakanishi T, Hashimoto K, Fischer U, et al. Constitutive high expression of interleukin-4/13A and GATA-3 in gill and skin of salmonid fishes suggests that these tissues form Th2-skewed immune environments. Mol Immunol. 2011:48:1360-8.

52. Chakir $\mathrm{H}$, Wang $\mathrm{H}$, Lefebvre DE, Webb J, Scott FW. T-bet/GATA-3 ratio as a measure of the Th1/Th2 cytokine profile in mixed cell populations: predominant role of GATA-3. J Immunol Methods. 2003;278:157-69.

53. Gorgoglione B, Wang T, Secombes CJ, Holland JW. Immune gene expression profiling of proliferative kidney disease in rainbow trout Oncorhynchus mykiss reveals a dominance of anti-inflammatory, antibody and T helper cell-like activities. Vet Res. 2013;44:55.

54. Ribeiro CMS, Pontes MJSL, Bird S, Chadzinska M, Scheer M, Verburg-van Kemenade BML, et al. Trypanosomiasis-induced Th17-like immune responses in carp. PLoS One. 2010;5:e13012.

55. Dienz O, Rincon M. The effects of IL-6 on CD4 T cell responses. Clin Immunol. 2009;130:27-33.

56. Manel N, Unutmaz D, Littman DR. The differentiation of human $\mathrm{T}(\mathrm{H})-17$ cells requires transforming growth factor-beta and induction of the nuclear receptor RORgammat. Nat Immunol. 2008;9:641-9.

57. Saraiva M, O'Garra A. The regulation of IL-10 production by immune cells. Nat Rev Immunol. 2010;10:170-81.

58. Piazzon MC, Wentzel AS, Wiegertjes GF, Forlenza M. Carp II10a and I10b exert identical biological activities in vitro, but are differentially regulated in vivo. Dev Comp Immunol. 2017;67:350-60.

59. Fischer U, Utke K, Somamoto T, Kollner B, Ototake M, Nakanishi T. Cytotoxic activities of fish leucocytes. Fish Shellfish Immunol. 2006;20:209-26.

60. Shibasaki Y, Toda H, Kobayashi I, Moritomo T, Nakanishi T. Kinetics of CD4+ and CD8alpha+ T-cell subsets in graft-versus-host reaction (GVHR) in ginbuna crucian carp Carassius auratus langsdorfii. Dev Comp Immunol. 2010;34:1075-81.

61. Toda H, Shibasaki Y, Koike T, Ohtani M, Takizawa F, Ototake M, et al. Alloantigen-specific killing is mediated by CD8-positive T cells in fish. Dev Comp Immunol. 2009;33:646-52.

62. Nayak SK, Nakanishi T. Direct antibacterial activity of CD8+/CD4+ T-cells in ginbuna crucian carp, Carassius auratus langsdorfii. Fish Shellfish Immunol. 2013;34:136-41.

63. Rau L, Gantress J, Bell A, Stewart R, Horton T, Cohen N, et al. Identification and characterization of Xenopus CD8+ T cells expressing an NK cellassociated molecule. Eur J Immunol. 2002;32:1574-83.

64. Cordero H, Cuesta A, Meseguer J, Esteban MA. Characterization of the gilthead seabream (Sparus aurata L.) immune response under a natural lymphocystis disease virus outbreak. J Fish Dis. 2016;39:1467-76.

65. Takizawa F, Dijkstra JM, Kotterba P, Korytár T, Kock H, Köllner B, et al. The expression of CD8a discriminates distinct $T$ cell subsets in teleost fish. Dev Comp Immunol. 2011;35:752-63.

66. Bratke K, Kuepper M, Bade B, Virchow JC Jr, Luttmann W. Differential expression of human granzymes $A, B$, and $K$ in natural killer cells and during CD8+ T cell differentiation in peripheral blood. Eur J Immunol. 2005;35:2608-16.

67. Braden LM, Rasmussen KJ, Purcell SL, Ellis L, Mahony A, Cho S, et al. Acquired protective immunity in Atlantic salmon Salmo salar against the myxozoan Kudoa thyrsites involves induction of MHIlbeta(+) CD83(+) antigen-presenting cells. Infect Immun. 2018;86:e00556-17.

68. Oykhman P, Mody CH. Direct microbicidal activity of cytotoxic Tlymphocytes. J Biomed Biotechnol. 2010;2010:249482.
69. Cuesta A, Salinas I, Rodríguez A, Muñoz P, Sitjà-Bobadilla A, ÁlvarezPellitero $P$, et al. Cell-mediated cytotoxicity is the main innate immune mechanism involved in the cellular defence of gilthead seabream (Teleostei: Sparidae) against Enteromyxum leei (Myxozoa). Parasite Immunol. 2006;28:657-65.

70. Sato A, Somamoto T, Yokooka H, Okamoto N. Systemic priming of alloreactive cytotoxic cells in carp, following anal administration of allogeneic cell antigens. Fish Shellfish Immunol. 2005;19:43-52.

71. Davey GC, Calduch-Giner JA, Houeix B, Talbot A, Sitjà-Bobadilla A, Prunet P, et al. Molecular profiling of the gilthead sea bream (Sparus aurata L.) response to chronic exposure to the myxosporean parasite Enteromyxum leei. Mol Immunol. 2011;48:2102-12.

72. Sitjà-Bobadilla A, Calduch-Giner J, Saera-Vila A, Palenzuela O, ÁlvarezPellitero P, Pérez-Sánchez J. Chronic exposure to the parasite Enteromyxum leei (Myxozoa: Myxosporea) modulates the immune response and the expression of growth, redox and immune relevant genes in gilthead sea bream, Sparus aurata L. Fish Shellfish Immunol. 2008;24:610-9.

73. Opazo JC, Butts GT, Nery MF, Storz JF, Hoffmann FG. Whole-genome duplication and the functional diversification of teleost fish hemoglobins. Mol Biol Evol. 2013:30:140-53.

74. Stocchi V, Wang T, Randelli E, Mazzini M, Gerdol M, Pallavicini A, et al. Evolution of Th2 responses: characterization of $\mathrm{LL}-4 / 13$ in sea bass (Dicentrarchus labrax L.) and studies of expression and biological activity. Sci Rep. 2017;7:2240.

\section{Ready to submit your research? Choose BMC and benefit from:}

- fast, convenient online submission

- thorough peer review by experienced researchers in your field

- rapid publication on acceptance

- support for research data, including large and complex data types

- gold Open Access which fosters wider collaboration and increased citations

- maximum visibility for your research: over $100 \mathrm{M}$ website views per year

At BMC, research is always in progress.

Learn more biomedcentral.com/submissions 